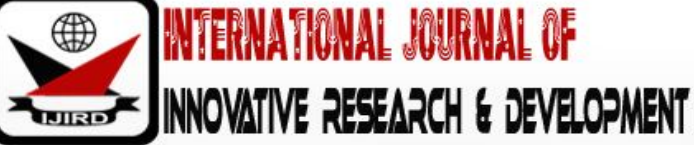

ISSN 2278 - 0211 (Online)

\section{Knowledge, Attitude and Practices of Sexually Transmitted Infections: Perceptions of Sexual Behaviour among Undergraduate Students in Lokoja, Nigeria}

\author{
Dr. Kennedy Oberhiri Obohwemu \\ Medical Practitioner, Federal Medical Centre, Lokoja, Nigeria
}

\begin{abstract}
:
Background: Sexually transmitted infections (STIs) are a major problem among Nigerian adolescents, with serious complications arising from untreated cases. Considering the growing trend of unprotected sex in this vulnerable population, it is pertinent to carry out interventions aimed at increasing awareness measures and lowering the disease burden.

Aims: To assess the knowledge, attitudes and practices of undergraduate students regarding STIs, including HIV/ AIDS.

Study Design: Descriptive cross-sectional study.

Place of Study: Federal University, Lokoja, Nigeria.

Duration of Study: Between October 2016 and March 2017.

Methods: A descriptive cross-sectional population-based study using self-administered structured questionnaires was carried out. A total of 370 undergraduate students were purposively selected to participate in the study. Data were analysed using SPSS software. Statistical measures like frequency, percentage and mean were tabulated.

Results: Out of the 370 students that participated in this study, only $66.2 \%$ knew the full meaning of HIV/ AIDS. The internet was the most common source of STI knowledge (92.2\%). A number of misconceptions were commonly reported among the respondents: $82.4 \%$ believed STIs could be transmitted by sharing a toilet seat, while $20.3 \%$ believed witchcraft was a means through which STIs could be transmitted. Only $22.2 \%$ knew that premature birth was a complication of untreated STIs. 83.5\% believed there was a cure for all STIs, including HIV/ AIDS. 70.5\% were worried about getting STIs when having unprotected sex. $77.8 \%$ were sexually active. As much as $79.7 \%$ had their first sexual encounter before their twentieth birthday. $74.9 \%$ had multiple sex partners. Only $18.9 \%$ used a condom every time they had sex. $45.9 \%$ used alcohol and/or other hard drugs before having sex. Only $44.3 \%$ had been tested for HIV.

Conclusion: Lack of in-depth knowledge about STIs coupled with risky sexual behaviours among undergraduate students of Federal University, Lokoja call for urgent measures to address the unfortunate trend.
\end{abstract}

Keywords: Sexually transmitted infections, sexual behaviour, undergraduate students

\section{Introduction}

The World Health Organisation (WHO) defines sexually transmitted infections (STIs) as infections that can be transferred from person to person primarily through sexual contacts ${ }^{1}$. The various forms of sexual contacts identified include vaginal, oral, and anal intercourse 2 .

Globally, STIs constitute a major public health challenge3. Countries in sub-Saharan Africa carry the highest disease burden ${ }^{4}$. Young adults aged 15-29 years are the population groups at the highest risks of contracting STIs ${ }^{5}$. STIs are among the top five disease categories for which young adults in developing countries seek health care services ${ }^{4}$. Prevalence rates of STIs among students of higher institutions are on the increase, and so are their long-term complications, like infertility and cervical cancer ${ }^{3}$.

Over 333 million new cases of STIs are reported each year, and two-thirds of these occur in young adults aged 25 years and below1. More than 110 million old and new STI cases have been recorded in the United States alone ${ }^{6}$. About 20 million new cases are reported annually, with over $50 \%$ occurring in the nation's youthful population ${ }^{3}$. These infections consume an estimated $\$ 16$ billion in total medical costs 6 .

A number of factors are responsible for the prevalence of STIs in the young adult population of developing nations like Nigeria. Some of these factors include early onset of menarche, erosion of traditional norms and values, westernization, adoption of foreign cultures, peer pressure, mass media influences, and a host of others 7,8 .

The most common STIs confronting young adults include HIV/ AIDS, gonorrhoea, chlamydia, trichomoniasis, genital warts, genital herpes, hepatitis B and syphilis ${ }^{6}$. Others are non-specific urethritis, lymphogranuloma venerum and vulvo-vaginitis ${ }^{9}$. These diseases pose a huge threat to adolescent health and survival. 
Data for STI prevalence rates in Nigeria are not readily available, due mainly to the fact that most cases are underreported. Access to health facilities are limited, diagnostic equipment is in short supply, and most STI cases are asymptomatic (i.e., signs and symptoms are not always present). Affected persons are easily stigmatized, so the options of self-medication and traditional healers are often explored.

There is too little research from Nigeria that focus on knowledge, attitudes and practices regarding STIs among young persons. It is therefore necessary to carry out this study so that current information concerning the perceptions of sexual behaviour among undergraduate students in Nigeria will be readily available. The study will evaluate the knowledge and attitudes of the students towards the practice of safe sex, and how they cope with STIs in general.

The findings of this research will be useful in revealing valuable information about the current knowledge, attitudes and practices of undergraduate students towards STIs in Nigeria. This information will help policy makers tailor interventions towards curbing the problems associated with STIs. By raising awareness in its own right, the research will serve as an advocacy tool to intensify ongoing efforts to control the spread of HIV/ AIDS among youths, as well as address reproductive health education issues in Nigeria. The research will also help the university authorities effect necessary changes in the existing STI prevention methods. Lastly, the findings of this research are expected to stimulate further research on the subject of STIs with widespread application in colleges, polytechnics and universities.

\section{Materials and Methods}

\subsection{Study Design}

A descriptive cross-sectional study was carried out using a case-study design that involved the self-administration of structured questionnaires to undergraduate students of Federal University, Lokoja. A pilot study was conducted in another tertiary institution in a neighbouring town (Federal College of Education, Okene, located some kilometers from Lokoja).

\subsection{Study Area}

The area covered by this study lies in Lokoja Local Government Area of Kogi State, in the North-Central geopolitical zone of Nigeria10,11,12. The city itself, Lokoja, lies at the confluence of Rivers Niger and Benue11,12,13. The coordinates are Latitude 7049' $\mathrm{N}$ and Longitude 6045'E, meaning the city lies about 7.80 North of the Equator and $6.7^{\circ}$ East of the Greenwich Meridian ${ }^{14,15,16 .}$

\subsection{Study Population}

The study population included students in all class levels of Federal University, Lokoja, except fresh year students (i.e., only students from 200L to 400L were considered). The university was yet to admit fresh (100L) students as at the time this study was being carried out.

\subsection{Sampling Technique}

Since the university is divided into faculties and further into departments, stratified random sampling was used to get the exact number of students per class level that will participate in the study. Only undergraduate students of Nigerian origin fully registered with the university were eligible to participate in the study. The selected students were also ready and willing to participate. Postgraduate students, international students and lecturers were excluded.

\subsection{Data Collection Method}

A total of 405 structured questionnaires were self-administered in all faculties and departments, and across various class levels.

\subsection{Data Analysis}

The questionnaires were manually sorted out, assigned code names and numbers, and analysed using the Statistical Package for Social Sciences (SPSS version 21.0) computer software. Simple descriptive statistics were used to organize and interpret the collected data. Statistical measures like frequency, percentage and mean were analyzed, with cross tabulation of variables for easy graphical representation. Bivariate and multivariate analysis were also done to determine associations between variables.

\subsection{Ethical Issues}

Being a research project submitted for the Master of Public Health (MPH) program at the University of Roehampton, London, for which Constance Shumba served as Project Supervisor, prior approval for the study was obtained from the relevant Ethics Committee of the university to carry out this study. Official written permission was also obtained from the management of Federal University, Lokoja to interview their students.

\subsection{Limitations of the Study}

First-year students were unavailable for the study. The university was yet to admit fresh students at the time this study was being carried out. If fresh (100L) students had been available, the target population would have increased significantly. This increase would have made the sample size more representative of the population.17,18,19 To make up for this, the sample size (which was originally meant to be 245 from calculations) was increased to 405. 


\section{Results}

Part of the objective of this research is to determine the level of knowledge of the students about STIs. The findings are presented here.

\subsection{Demographic Characteristics}

A sum total of four hundred and five (405) questionnaires were administered to undergraduate students of Federal University, Lokoja. Three Hundred and Ninety-One (391) questionnaires were retrieved, out of which twenty-one (21) were poorly filled and hence rejected. Data analysis was therefore carried out with Three Hundred and Seventy (370) questionnaires, which translates to $91.4 \%$ response rate.

Of the 370 respondents, 160 were in their 2 nd year, 89 in their 3rd year and 121 in their 4th year. Students were drawn from all three streams (Science, Commerce and Arts) in the university. In total, 230 were males and 140 were females (males almost twice as many as females). These demographic characteristics (sex, age, class level and stream) are presented in Table 1.

\begin{tabular}{|c|c|c|c|c|c|}
\hline \multicolumn{7}{|c|}{ Year of Study } \\
\hline & $\begin{array}{c}\text { 100L } \\
\text { (1st Year) (\%) }\end{array}$ & $\begin{array}{c}\text { 200L } \\
\text { (2nd Year) (\%) }\end{array}$ & $\begin{array}{c}300 \mathrm{~L} \\
(3 \mathrm{rd} \mathrm{Year})(\%)\end{array}$ & $\begin{array}{c}400 \mathrm{~L} \\
(4 \mathrm{th} \text { Year) (\%) }\end{array}$ & $\begin{array}{c}\text { Total } \\
(\%)\end{array}$ \\
\hline Male & $0(0 \%)$ & $94(59 \%)$ & $56(63 \%)$ & $80(66 \%)$ & $230(62 \%)$ \\
\hline Female & $0(0 \%)$ & $66(41 \%)$ & $33(37 \%)$ & $41(34 \%))$ & $140(38 \%)$ \\
\hline Total & $0(0 \%)$ & $160(100 \%)$ & $89(100 \%)$ & $121(100 \%)$ & $370(100 \%)$ \\
\hline
\end{tabular}

Table 1: Sex Distribution of Respondents

The respondents were aged between 18-36 years, with a mean age of 24.31 ( $\mathrm{SD}=1.047$ ). The modal age group was 21-23 years. 64 of the respondents (17.3\%) chose not to reveal their age, despite their anonymous status. The age distribution (raw data) is shown in Fig. 1.

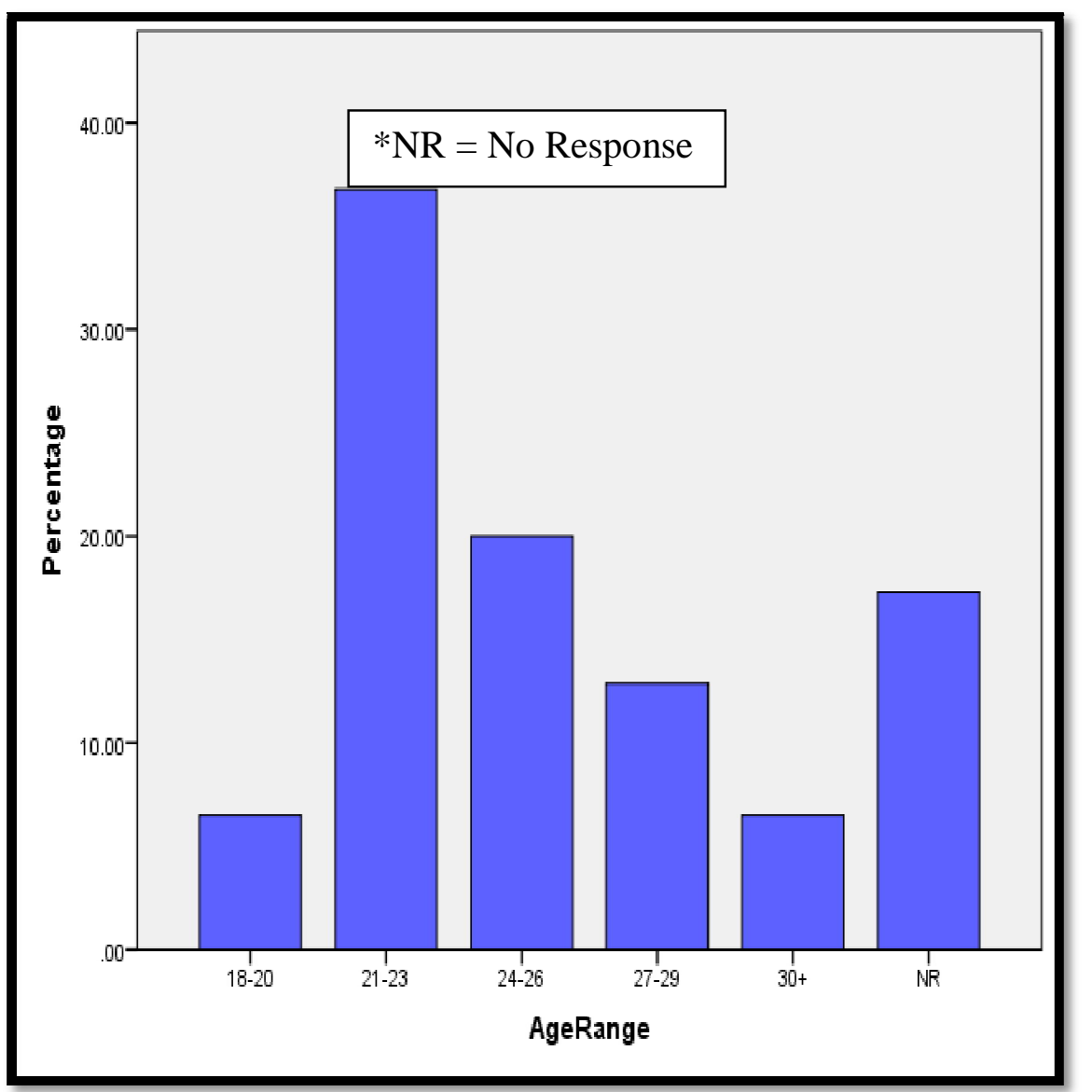

Figure 1: Bar Chart Showing Age Distribution of Respondents

Most of the participants were Science students (47.3\%). Commerce and Arts students made up $11.3 \%$ and $41.4 \%$ of the sample population respectively (see Fig. 2 below). 


\section{Stream Distribution of Respondents}

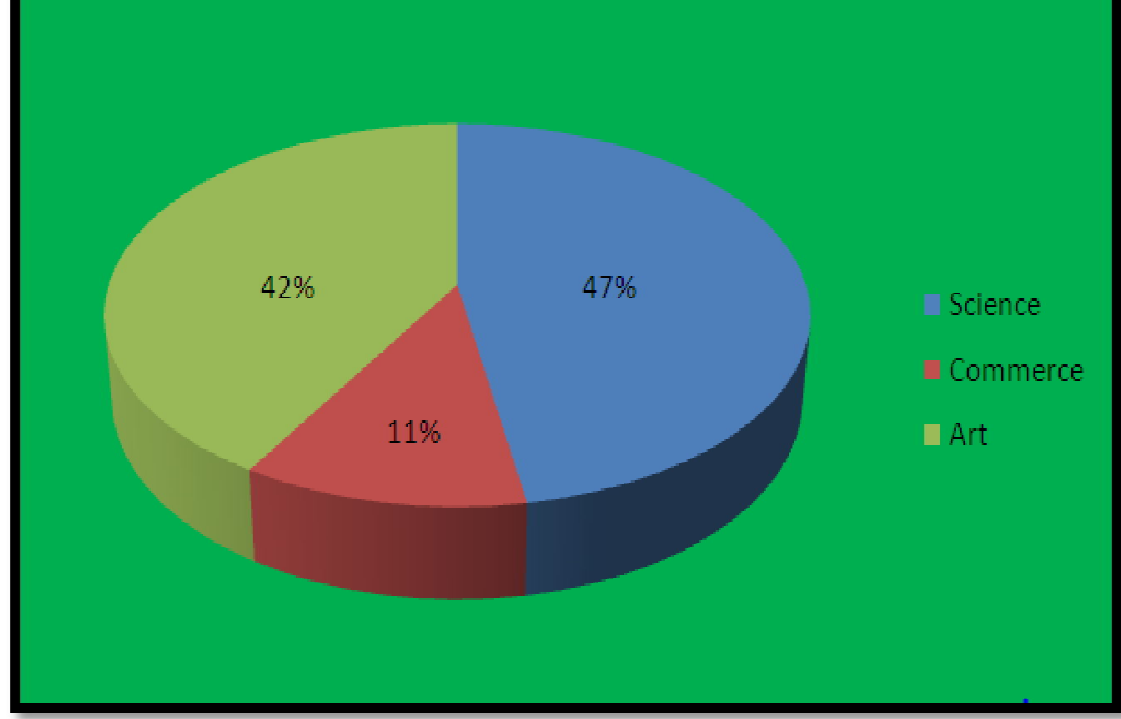

Figure 2: Pie Chart Showing Stream Distribution of Respondents

3.2. Knowledge of STIs

\subsubsection{Awareness of HIV/ AIDS}

All the students who participated in this study (100\%) had heard about HIV/ AIDS (see Table 2).

\begin{tabular}{|c|c|c|}
\hline Types of STIs & Frequency & Percentage (\%) \\
\hline HIV/ AIDS & 370 & 100 \\
\hline Gonorrhoea & 358 & 96.8 \\
\hline Chlamydia & 115 & 31.1 \\
\hline Trichomoniasis & 109 & 29.5 \\
\hline Genital warts & 142 & 38.4 \\
\hline Genital herpes & 155 & 41.9 \\
\hline Hepatitis B & 249 & 67.3 \\
\hline Syphilis & 339 & 91.6 \\
\hline
\end{tabular}

Table 2: Knowledge of STIs (Including HIV/ AIDS) Among Respondents

It is important to note that even though all the students (100\%) who took part in this research had heard about HIV/ AIDS, not all of them knew what the acronym stood for. In fact, only about two-thirds (66.2\%) knew the full meaning of HIV/ AIDS.

\subsubsection{Knowledge about Other STIs}

Apart from HIV/ AIDS, most of the respondents knew of the existence of other STIs like gonorrhoea, chlamydia, trichomoniasis, genital warts, genital herpes, hepatitis B and syphilis. Gonorrhoea (96.8\%) and syphilis (91.6\%) were the most common STIs known by the $91.4 \%$ respondents, while trichomoniasis $(29.5 \%)$ and chlamydia (31.1\%) were the least known (see Fig. 3). 


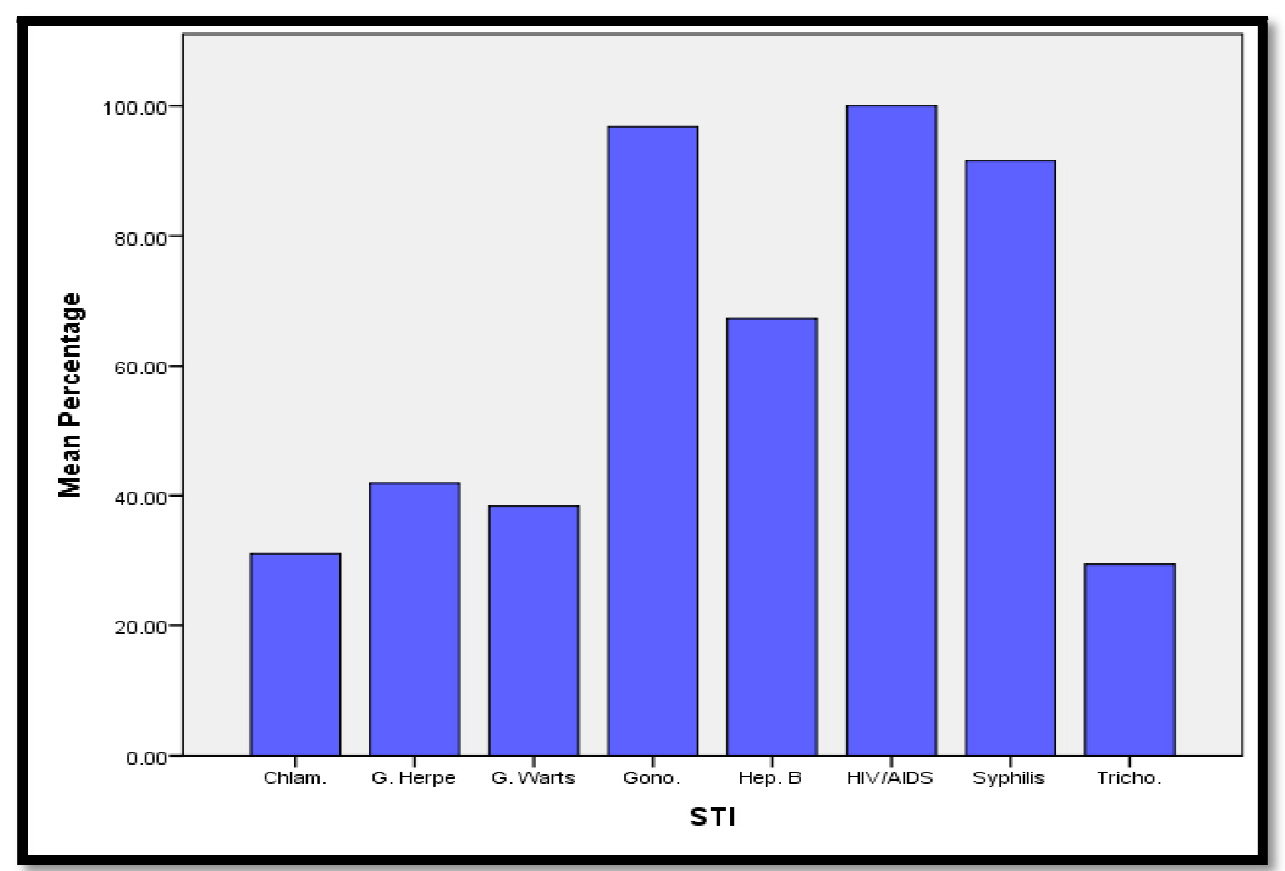

Figure 3: Bar Chart Showing Respondents' Awareness Levels of STIs

\subsubsection{Sources of Knowledge about STIs (Including HIV/ AIDS)}

This study sought to know the means through which respondents gained access to information regarding STIs. Various options were given to the respondents, including but not restricted to the following: friends, family, internet, television, radio, magazine, school/ college, hospital/ clinic. The internet was the highest source of knowledge (92.2\%) among the respondents (see Table 3).

\begin{tabular}{|c|c|c|}
\hline Source of Knowledge & Frequency & Percentage (\%) \\
\hline Friends & 323 & 87.3 \\
\hline Family & 233 & 62.9 \\
\hline Internet & 341 & 92.2 \\
\hline Television & 274 & 74.1 \\
\hline Radio & 126 & 34.1 \\
\hline Newspapers/ Magazines & 255 & 68.9 \\
\hline School/ College & 249 & 67.3 \\
\hline Hospital/Clinic & 315 & 85.1 \\
\hline Others & 92 & 24.9 \\
\hline
\end{tabular}

Table 3: Sources of Knowledge about STIs (Including HIV/ AIDS) among Respondents

\subsubsection{Knowledge about Routes of Transmission of STIs (Including HIV/ AIDS)}

Most of the respondents had a good knowledge of the basic routes of transmission of STIs (Table 4). Unprotected sex (93.2\%) and blood transfusion (89.2\%) were the most commonly cited routes of STI transmission. Others were mother to unborn child (87.8\%) and sharing of sharp objects (81.1\%). However, there were some respondents who held on to a number of false, mistaken beliefs regarding routes of STI transmission. A remarkable $82.4 \%$ of the respondents believed STIs could be transmitted by sharing a toilet seat and the erroneous term "toilet infection" was usually used by these respondents in place of STIs. $67.6 \%$ of the respondents believed STIs could be transmitted through kissing, while $27.0 \%$ believed handshake was another route of transmission. 20.3\% believed witchcraft was a means through which STIs could be transmitted.

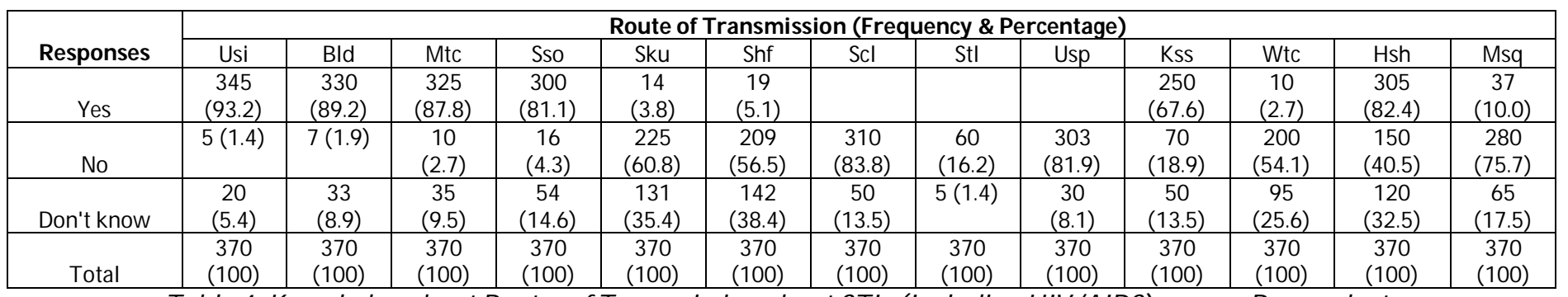

Table 4: Knowledge about Routes of Transmission about STIs (Including HIV/ AIDS) among Respondents

Key: USI - Unprotected Sexual Intercourse; BLD - Blood Transfusion; MTC - Mother to Unborn Child; SSO - Sharing Sharp

Objects; SKU - Sharing Kitchen Utensils; SHF - Sharing Food; SCL - Sharing Clothes; STL - Sharing Toilet; USP - Using Same Swimming Pool; KSS - Kissing; WTC - Witchcraft; HHS - Handshake; MSQ - Mosquito Bites 


\subsubsection{Knowledge about Signs and Symptoms of STIs (Including HIV/ AIDS)}

The most common signs and symptoms of STIs (including HIV/ AIDS) reported by the respondents were weight loss (96.7\%), abdominal pain (92.7\%), genital discharge (88.4\%), skin rash (84.1\%) and recurrent fever (83.5\%) (see Table 9).

\begin{tabular}{|c|c|c|c|c|c|c|c|c|c|c|c|c|c|}
\hline \multirow[b]{2}{*}{ Responses } & \multicolumn{13}{|c|}{ Signs \& Symptoms (Frequency \& Percentage) } \\
\hline & $\mathrm{Rfv}$ & Rws & Skr & Wtl & Gdc & Pwu & Gul & Bss & Lum & Awp & Pds & Biu & Gbw \\
\hline Yes & 309 (83.5) & $\begin{array}{c}201 \\
(54.3)\end{array}$ & $\begin{array}{c}311 \\
(84.1)\end{array}$ & $\begin{array}{c}358 \\
(96.7)\end{array}$ & $\begin{array}{c}327 \\
(88.4)\end{array}$ & $\begin{array}{c}88 \\
(23.8)\end{array}$ & $\begin{array}{c}112 \\
(30.3)\end{array}$ & $26(7.0)$ & $\begin{array}{c}9 \\
(2.4)\end{array}$ & $\begin{array}{c}343 \\
(92.7)\end{array}$ & $\begin{array}{c}290 \\
(78.4)\end{array}$ & $\begin{array}{c}70 \\
(18.9)\end{array}$ & $\begin{array}{c}123 \\
(33.2)\end{array}$ \\
\hline No & $13(3.5)$ & $\begin{array}{c}69 \\
(18.6)\end{array}$ & $17(4.6)$ & $8(2.2)$ & $\begin{array}{c}38 \\
(10.3)\end{array}$ & $8(2.1)$ & $3(0.8)$ & $25(6.8)$ & $10(2.7)$ & $6(1.6)$ & $12(3.2)$ & $\begin{array}{c}61 \\
(16.5)\end{array}$ & $\begin{array}{c}207 \\
(55.9)\end{array}$ \\
\hline Don't know & $48(13.0)$ & $\begin{array}{c}100 \\
(27.1)\end{array}$ & $\begin{array}{c}42 \\
(11.3)\end{array}$ & $4(1.1)$ & $5(1.3)$ & $\begin{array}{c}274 \\
(74.1)\end{array}$ & $\begin{array}{c}255 \\
(68.9)\end{array}$ & $\begin{array}{c}319 \\
(86.2)\end{array}$ & $\begin{array}{c}351 \\
(94.9)\end{array}$ & $21(5.7)$ & $\begin{array}{c}68 \\
(18.4)\end{array}$ & $\begin{array}{c}239 \\
(64.6)\end{array}$ & $\begin{array}{c}40 \\
(10.9)\end{array}$ \\
\hline Total & $370(100)$ & $\begin{array}{c}370 \\
(100)\end{array}$ & $\begin{array}{c}370 \\
(100)\end{array}$ & $\begin{array}{c}370 \\
(100)\end{array}$ & $\begin{array}{c}370 \\
(100)\end{array}$ & $\begin{array}{c}370 \\
(100)\end{array}$ & $\begin{array}{c}370 \\
(100)\end{array}$ & $\begin{array}{c}370 \\
(100)\end{array}$ & $\begin{array}{c}370 \\
(100)\end{array}$ & $\begin{array}{c}370 \\
(100)\end{array}$ & $\begin{array}{c}370 \\
(100)\end{array}$ & $\begin{array}{c}370 \\
(100)\end{array}$ & $\begin{array}{c}370 \\
(100)\end{array}$ \\
\hline
\end{tabular}

Table 5: Knowledge about Signs and Symptoms of STIs (Including HIV/ AIDS) among Respondents

Key: RFV - Recurrent Fever; RWS - Recurrent Watery Stools (Diarrhoea); SKR - Skin Rash ( Sometimes Itchy); WTL - Weight Loss; GDC - Genital Discharge/ Itching (Sometimes Smelly); PWU - Pain When Urinating; GUL - Genital Ulcers ( Sores); BSS -

Burning Sensation; LUM - Lumps (Swollen Lymph Nodes); AWP - Abdominal/Waist Pain; PDS - Pain During Sexual Intercourse; BIU - Blood in Urine; GBW - General Body Weakness

On the average, $58 \%$ of the respondents agreed that it was possible for a person (a man or a woman) to have an STI without having any symptoms. $76 \%$ admitted to have had at least one of the STI symptoms listed (although they may not necessarily have an STI as symptoms could overlap with other disease entities). 87\% said they knew someone who had been diagnosed with at least one STI.

\subsubsection{Knowledge about Preventive Measures of STIs (Including HIV/ AIDS)}

The respondents displayed a relatively high level of awareness of STI preventive measures (Table 6). Condom use (94.1\%) was the most frequently known preventive measure, followed by abstinence (90.0\%) and being faithful to one uninfected partner (84.6\%).

\begin{tabular}{|c|c|c|c|c|c|c|c|c|c|c|}
\hline \multirow{2}{*}{ Responses } & \multicolumn{8}{|c|}{ Knowledge about Preventive Measures (Frequency \& Percentage) } \\
\cline { 2 - 11 } & Afs & Con & Fai & Msp & Csw & Dos & Uas & Trs & Tpw & Ucp \\
\hline & 333 & 348 & 313 & 294 & 299 & 39 & 202 & 301 & 305 & 236 \\
Yes & $(90.0)$ & $(94.1)$ & $(84.6)$ & $(79.5)$ & $(80.8)$ & $(10.5)$ & $(54.6)$ & $(81.4)$ & $(82.4)$ & $(63.8)$ \\
\hline & 13 & 16 & $7(1.9)$ & 37 & 12 & 43 & 110 & 55 & 18 & 101 \\
No & $(3.5)$ & $(4.3)$ & & $(10.0)$ & $(3.2)$ & $(11.6)$ & $(29.7)$ & $(14.9$ & $(4.9)$ & $(27.3)$ \\
\hline \multirow{2}{*}{ Don't know } & 24 & $6(1.6)$ & 50 & 39 & 59 & 288 & 58 & 14 & 47 & 33 \\
& $(6.5)$ & & $(13.5)$ & $(10.5)$ & $(16.0)$ & $(77.9)$ & $(15.7)$ & $(3.7)$ & $(12.7)$ & $(8.9)$ \\
\hline \multirow{2}{*}{ Total } & 370 & 370 & 370 & 370 & 370 & 370 & 370 & 370 & 370 & 370 \\
& $(100)$ & $(100)$ & $(100)$ & $(100)$ & $(100)$ & $(100)$ & $(100)$ & $(100)$ & $(100)$ & $(100)$ \\
\hline
\end{tabular}

Table 6: Knowledge about Preventive Measures of STIS (Including HIV/ AIDS) among Respondents

Key: AFS - Abstaining from Sex; Con - Condoms; Fai - Being Faithful to One Uninfected Partner; MSP - Avoiding Multiple Sexual Partners; CSW - Avoiding Sex with Commercial Sex Workers; Dos - Delaying Onset of Sex; UAS - Urinating After Sex; TRS -

Transfusing Tested Safe Blood; TPW - Treating a Positive Pregnant Woman; UCP - Using Contraceptive Pills

\subsubsection{Knowledge about Complications of Untreated STIs (Including HIV/ AIDS)}

Majority of the respondents were unaware of the complications of untreated STIs (Table 7). Only $22.2 \%$ of the respondents knew that premature birth was a complication untreated STIs. Knowledge levels were lower for infertility $(21.1 \%)$ and miscarriage $(19.2 \%)$. As much as $69.7 \%$ did not know that cervical cancer was a complication of untreated STIs.

\begin{tabular}{|c|c|c|c|c|c|c|}
\hline & \multicolumn{6}{|c|}{ Knowledge about Complications (Frequency \& Percentage) } \\
\cline { 2 - 7 } Responses & Infertility & Stillbirth & Miscarriage & $\begin{array}{c}\text { Premature } \\
\text { Birth }\end{array}$ & $\begin{array}{c}\text { Ectopic } \\
\text { Pregnancy }\end{array}$ & $\begin{array}{c}\text { Cervical } \\
\text { Cancer }\end{array}$ \\
\hline Yes & $78(21.1)$ & $66(17.8)$ & $71(19.2)$ & $82(22.2)$ & $54(14.6)$ & $57(15.4)$ \\
\hline No & $58(15.7)$ & $53(14.3)$ & $52(14.1)$ & $49(13.2)$ & $54(14.6)$ & $55(14.9)$ \\
\hline Don't know & $234(63.2)$ & $251(67.9)$ & $247(66.7)$ & $239(64.6)$ & $262(70.8)$ & $258(69.7)$ \\
\hline Total & $370(100)$ & $370(100)$ & $370(100)$ & $370(100)$ & $370(100)$ & $370(100)$ \\
\hline
\end{tabular}

Table 7: Knowledge about Complications of Untreated STIs (Including HIV/ AIDS) among Respondents

The respondents were asked if they were aware that STIs could be treated, and if they knew whether a cure (permanent solution) existed. Most of the respondents (94.1\%) knew that STIs are treatable. However, 83.5\% of them believed there was a cure for all STIs, including HIV/ AIDS. 
When the respondents were asked if they knew where to go for STI testing (and possibly access treatment), majority were positive in their responses (see Table 8). However, 36 respondents $(0.9 \%$ ) claimed they did not know that a General Practitioner could screen people for STIs (and possibly treat), whereas as many as 323 respondents (87.3\%) felt a Traditional healer could conduct STI testing (and treatment).

\begin{tabular}{|c|c|c|c|c|c|c|}
\hline \multirow[b]{2}{*}{ Responses } & \multicolumn{6}{|c|}{$\begin{array}{c}\text { Knowledge About Where to Get Screened for STIs (and Possibly Access Treatment) } \\
\text { (Frequency \& Percentage) }\end{array}$} \\
\hline & $\begin{array}{c}\text { General } \\
\text { practitioner }\end{array}$ & $\begin{array}{l}\text { Private } \\
\text { hospital }\end{array}$ & $\begin{array}{l}\text { Government } \\
\text { hospital }\end{array}$ & $\begin{array}{c}\text { STI } \\
\text { Clinic }\end{array}$ & $\begin{array}{c}\text { Private } \\
\text { laboratory }\end{array}$ & $\begin{array}{l}\text { Traditiona } \\
\text { healer }\end{array}$ \\
\hline Yes & $334(90.1)$ & $370(100)$ & $370(100)$ & $370(100)$ & $370(100)$ & $323(87.3)$ \\
\hline No & $0(0)$ & $0(0)$ & $0(0)$ & $0(0)$ & $0(0)$ & $20(5.4)$ \\
\hline Don't know & $36(0.9)$ & $0(0)$ & $0(0)$ & $0(0)$ & $0(0)$ & $27(7.3)$ \\
\hline Total & $370(100)$ & $370(100)$ & $370(100)$ & $370(100)$ & $370(100)$ & $370(100)$ \\
\hline
\end{tabular}

Table 8: Knowledge about Where to Get Screened for STIs (and Possibly Access Treatment)

\subsubsection{Gender Differences in Knowledge of STIs (Including HIV/ AIDS)}

Using Pearson's Chi-squared test for categorical data, no significant difference was observed between males and females regarding awareness levels of STIs ( $\mathrm{p}=1.000$ for each of the eight STIs listed).

Table 9 shows the results (raw data) obtained from the respondents concerning knowledge levels of the various STIs, classified according to gender. Tables 10-17 shows the analyzed values ( $\mathrm{p}$-values derived from SPSS software) for the respective STIs.

\begin{tabular}{|c|c|c|c|c|c|c|}
\hline \multirow[b]{3}{*}{ Types of STIs } & \multicolumn{5}{|c|}{ Frequency } & \multirow{3}{*}{$\begin{array}{c}\text { Percentage } \\
(\%)\end{array}$} \\
\hline & \multicolumn{2}{|c|}{ Male } & \multicolumn{2}{|r|}{ Female } & \multirow[b]{2}{*}{ Total } & \\
\hline & Yes & No/ Don't know & Yes & No/ Don't know & & \\
\hline HIV/ AIDS & 230 & 0 & 140 & 0 & 370 & 100 \\
\hline Gonorrhoea & 222 & 8 & 136 & 4 & 358 & 96.8 \\
\hline Chlamydia & 71 & 159 & 44 & 96 & 115 & 31.1 \\
\hline Trichomoniasis & 67 & 163 & 42 & 98 & 109 & 29.5 \\
\hline Genital warts & 88 & 142 & 54 & 86 & 142 & 38.4 \\
\hline Genital herpes & 96 & 134 & 59 & 81 & 155 & 41.9 \\
\hline Hepatitis B & 154 & 76 & 95 & 45 & 249 & 67.3 \\
\hline Syphilis & 211 & 19 & 128 & 12 & 339 & 91.6 \\
\hline
\end{tabular}

Table 9: Gender Differences in Knowledge of STIs (including HIV/ AIDS) among Respondents

\begin{tabular}{|c|c|c|c|c|c|c|}
\hline \multicolumn{7}{|c|}{ Case Processing Summary } \\
\hline & \multicolumn{6}{|c|}{ Cases } \\
\hline & \multicolumn{2}{|c|}{ Valid } & \multicolumn{2}{|c|}{ Missing } & \multicolumn{2}{|c|}{ Total } \\
\hline & $\mathrm{N}$ & Percent & $\mathrm{N}$ & Percent & $\mathrm{N}$ & Percent \\
\hline $\begin{array}{c}\text { Gender* } \\
\text { Knowledge of HIV/ AIDS }\end{array}$ & 4 & $100.0 \%$ & 0 & $0.0 \%$ & 4 & $100.0 \%$ \\
\hline \multicolumn{7}{|c|}{ Chi-Square Tests } \\
\hline & Value & Df & $\begin{array}{l}\text { Asymp. Sig } \\
\text { (2-sided) }\end{array}$ & & $\begin{array}{l}\text { act Sig. (2- } \\
\text { sided) }\end{array}$ & $\begin{array}{l}\text { Exact Sig. (1- } \\
\text { sided) }\end{array}$ \\
\hline Pearson Chi-Square & $.000^{\mathrm{a}}$ & 1 & 1.000 & & & \\
\hline Continuity Correction ${ }^{b}$ & .000 & 1 & 1.000 & & & \\
\hline Likelihood Ratio & .000 & 1 & 1.000 & & & \\
\hline Fisher's Exact Test & & & & & 1.000 & .833 \\
\hline $\begin{array}{l}\text { Linear-by-Linear } \\
\text { Association }\end{array}$ & .000 & 1 & 1.000 & & & \\
\hline N of Valid Cases & 4 & & & & & \\
\hline
\end{tabular}

Table 10: Gender Differences in Knowledge of HIV/ AIDS among Respondents

a. 4 Cells (100.0\%) Have Expected Count Less Than 5; The Minimum Expected Count Is 1.00

b. Computed Only For A 2x2 Table 


\begin{tabular}{|c|c|c|c|c|c|c|c|}
\hline \multicolumn{8}{|c|}{ Case Processing Summary } \\
\hline & \multicolumn{7}{|c|}{ Cases } \\
\hline & \multicolumn{2}{|c|}{ Valid } & \multicolumn{3}{|c|}{ Missing } & \multicolumn{2}{|c|}{ Total } \\
\hline & $\mathrm{N}$ & Percent & $\mathrm{N}$ & & & $\mathrm{N}$ & Percent \\
\hline $\begin{array}{c}\text { Gender } * \\
\text { Knowledge of } \\
\text { Gonorrhoea }\end{array}$ & 4 & $100.0 \%$ & 0 & & & 4 & $100.0 \%$ \\
\hline \multicolumn{8}{|c|}{ Chi-Square Tests } \\
\hline & Value & $\mathrm{df}$ & $\begin{array}{r}\text { Asyr } \\
(2-s\end{array}$ & & & l) $(2-$ & $\begin{array}{l}\text { Exact Sig. (1- } \\
\text { sided) }\end{array}$ \\
\hline Pearson Chi-Square & $.000^{\mathrm{a}}$ & 1 & & & & & \\
\hline Continuity Correction $^{b}$ & .000 & 1 & & & & & \\
\hline Likelihood Ratio & .000 & 1 & & & & & \\
\hline Fisher's Exact Test & & & & & & & .833 \\
\hline $\begin{array}{l}\text { Linear-by-Linear } \\
\text { Association }\end{array}$ & .000 & 1 & & & & & \\
\hline N of Valid Cases & 4 & & & & & & \\
\hline
\end{tabular}

Table 11: Gender Differences in Knowledge of Gonorrhoea among Respondents a. 4 Cells (100.0\%) Have Expected Count Less Than 5; the Minimum Expected Count Is 1.00. b. Computed Only for a 2x2 Table

\begin{tabular}{|c|c|c|c|c|c|c|c|}
\hline \multicolumn{8}{|c|}{ Case Processing Summary } \\
\hline & & & & as & & & \\
\hline & \multicolumn{2}{|c|}{ Valid } & \multicolumn{3}{|c|}{ Missing } & \multicolumn{2}{|c|}{ Total } \\
\hline & $\mathrm{N}$ & Percent & $\mathrm{N}$ & & & $\mathrm{N}$ & Percent \\
\hline $\begin{array}{c}\text { Gender* } \\
\text { Knowledge of Chlamvdia }\end{array}$ & 4 & $100.0 \%$ & 0 & & & 4 & $100.0 \%$ \\
\hline \multicolumn{8}{|c|}{ Chi-Square Tests } \\
\hline & Value & $\mathrm{df}$ & $\begin{array}{l}\text { Asyn } \\
(2-\mathrm{s}\end{array}$ & & & $\begin{array}{l}\text { ig. }(2- \\
\text { d) }\end{array}$ & $\begin{array}{l}\text { Exact Sig. (1- } \\
\text { sided) }\end{array}$ \\
\hline Pearson Chi-Square & $.000^{\mathrm{a}}$ & 1 & & & & & \\
\hline Continuity Correction ${ }^{\mathrm{b}}$ & .000 & 1 & & & & & \\
\hline Likelihood Ratio & .000 & 1 & & & & & \\
\hline Fisher's Exact Test & & & & & & & .833 \\
\hline $\begin{array}{l}\text { Linear-by-Linear } \\
\text { Association }\end{array}$ & .000 & 1 & & & & & \\
\hline N of Valid Cases & 4 & & & & & & \\
\hline
\end{tabular}

Table 12: Gender Differences in Knowledge of Chlamydia among Respondents

a. 4 Cells (100.0\%) Have Expected Count Less than 5; the Minimum Expected Count is 1.00.

b. Computed Only for A 2x2 Table

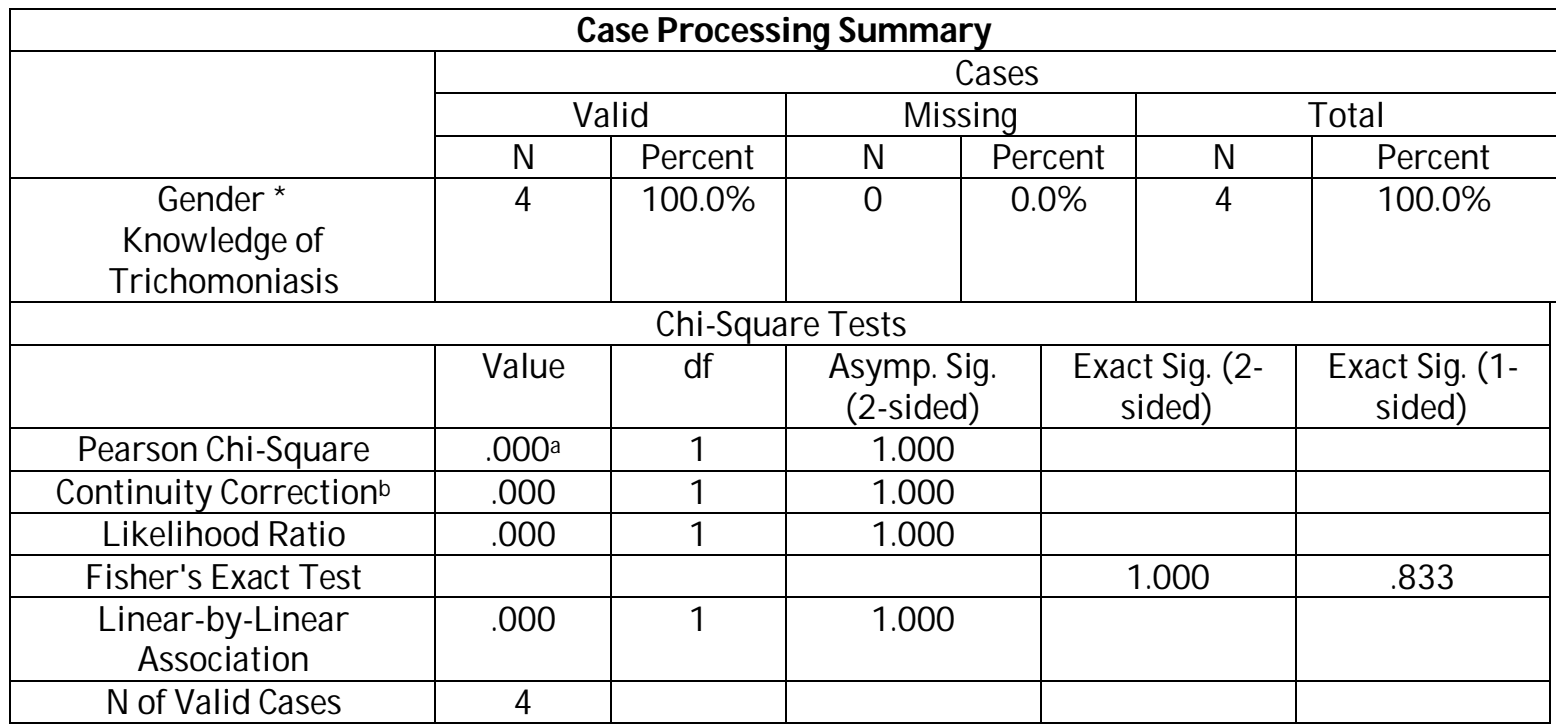

Table 13: Gender Differences in Knowledge of Trichomonia sis among Respondents

a. 4 Cells (100.0\%) Have Expected Count Less than 5; the Minimum Expected Count is 1.00.

b. Computed Only for A 2x2 Table 


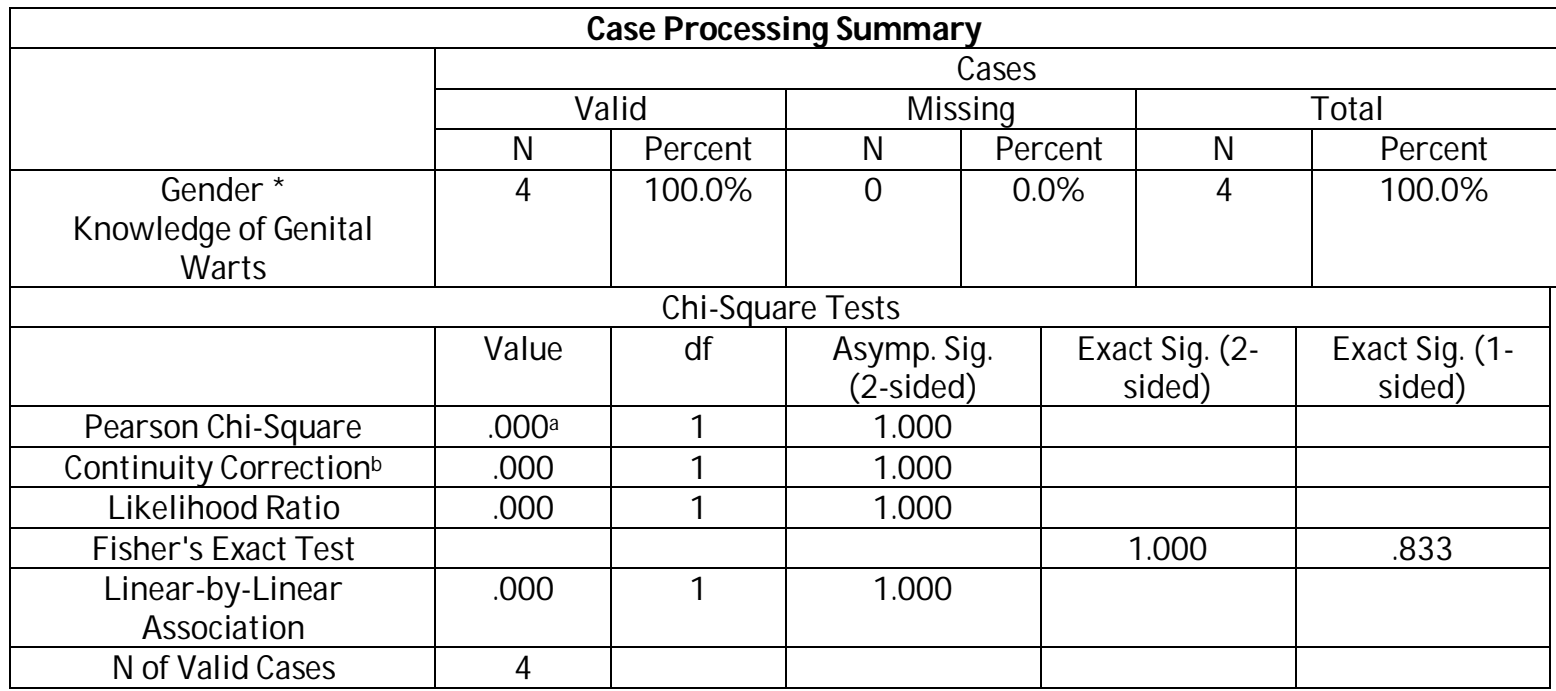

Table 14: Gender Differences in Knowledge of Genital Warts among Respondents

a. 4 Cells (100.0\%) Have Expected Count Less than 5, the Minimum Expected Count is 1.00

b. Computed Only for A 2x2 Table

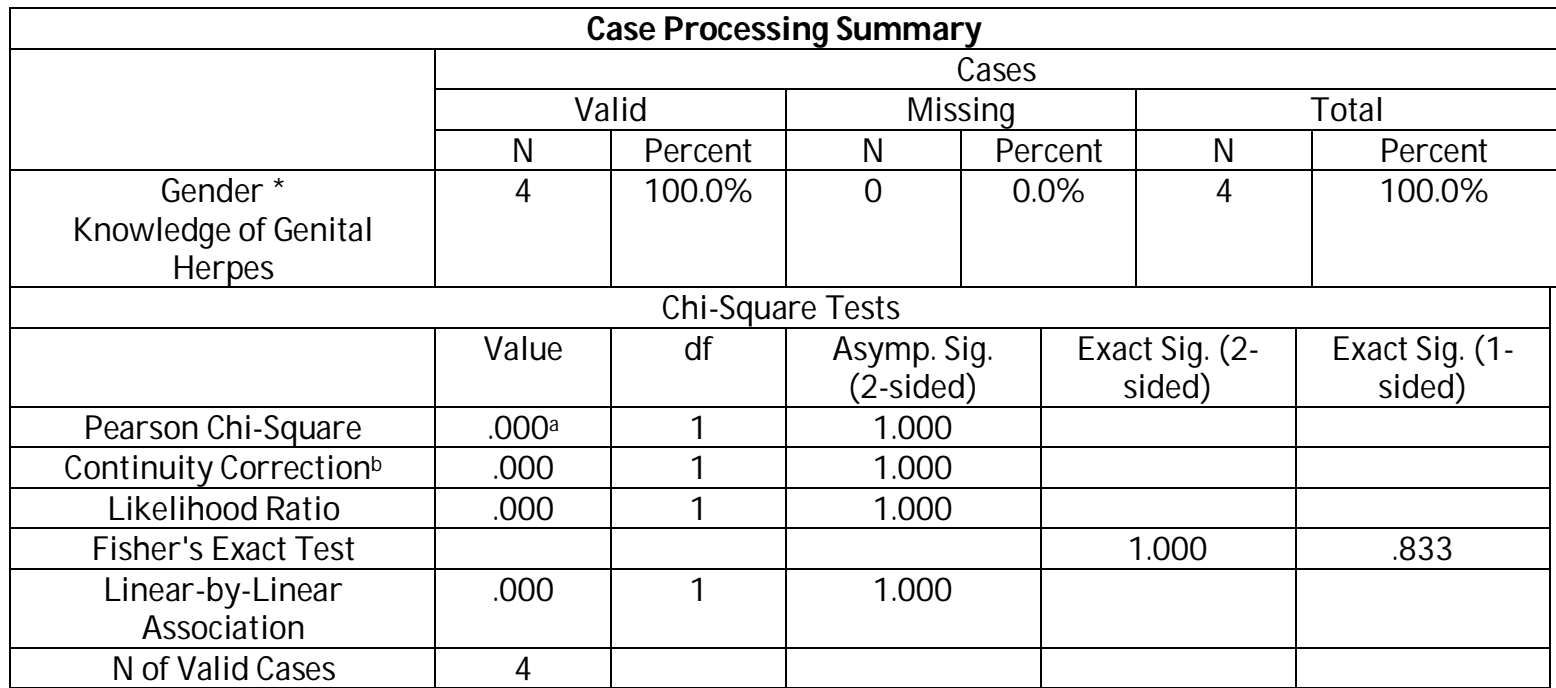

Table 15: Gender Differences in Knowledge of Genital Herpes among Respondents

a. 4 Cells (100.0\%) Have Expected Count Less than 5; the Minimum Expected Count is 1.00

b. Computed Only for a 2x2 Table

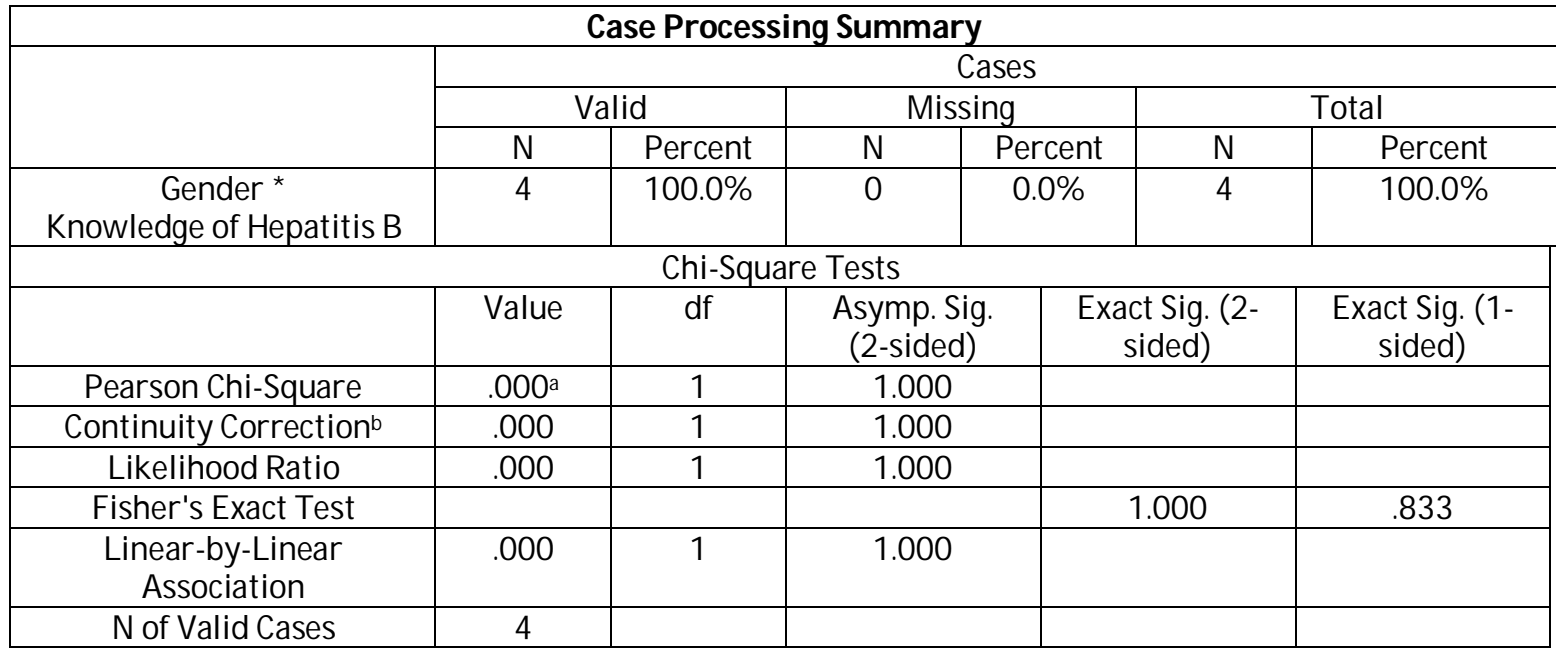

Table 16: Gender Differences in Knowledge of Hepatitis B among Respondents

a. 4 Cells (100.0\%) Have Expected Count Less than 5, the Minimum Expected Count is 1.00

b. Computed Only for A 2x2 Table 


\begin{tabular}{|c|c|c|c|c|c|c|}
\hline \multicolumn{7}{|c|}{ Case Processing Summary } \\
\hline & \multicolumn{6}{|c|}{ Cases } \\
\hline & \multicolumn{2}{|c|}{ Valid } & \multicolumn{2}{|c|}{ Missing } & \multicolumn{2}{|l|}{ Total } \\
\hline & $\mathrm{N}$ & Percent & $\mathrm{N}$ & Percent & $\mathrm{N}$ & Percent \\
\hline $\begin{array}{c}\text { Gender* } \\
\text { Knowledge of Syphilis }\end{array}$ & 4 & $100.0 \%$ & 0 & $0.0 \%$ & 4 & $100.0 \%$ \\
\hline \multicolumn{7}{|c|}{ Chi-Square Tests } \\
\hline & Value & $\mathrm{df}$ & $\begin{array}{l}\text { Asymp. Sig } \\
\text { (2-sided) }\end{array}$ & & $\begin{array}{l}\text { t Sig. (2- } \\
\text { ided) }\end{array}$ & $\begin{array}{l}\text { Exact Sig. (1- } \\
\text { sided) }\end{array}$ \\
\hline Pearson Chi-Square & $.000^{\mathrm{a}}$ & 1 & 1.000 & & & \\
\hline Continuity Correction $^{\mathrm{b}}$ & .000 & 1 & 1.000 & & & \\
\hline Likelihood Ratio & .000 & 1 & 1.000 & & & \\
\hline Fisher's Exact Test & & & & & .000 & .833 \\
\hline $\begin{array}{l}\text { Linear-by-Linear } \\
\text { Association }\end{array}$ & .000 & 1 & 1.000 & & & \\
\hline N of Valid Cases & 4 & & & & & \\
\hline
\end{tabular}

Table 17: Gender Differences in Knowledge of Syphilis among Respondents

a. 4 Cells (100.0\%) Have Expected Count Less Than 5; the Minimum Expected Count is 1.00

b. Computed Only for A 2x2 Table

\subsection{Attitude towards STIs}

Respondents were asked if they were worried about contracting STIs (including HIV/ AIDS) when having unprotected sexual intercourse. The responses are presented in Fig. 4. Majority (70.5\%) expressed concerns over contracting STIs (especially HIV/ AIDS) when having unprotected sex.

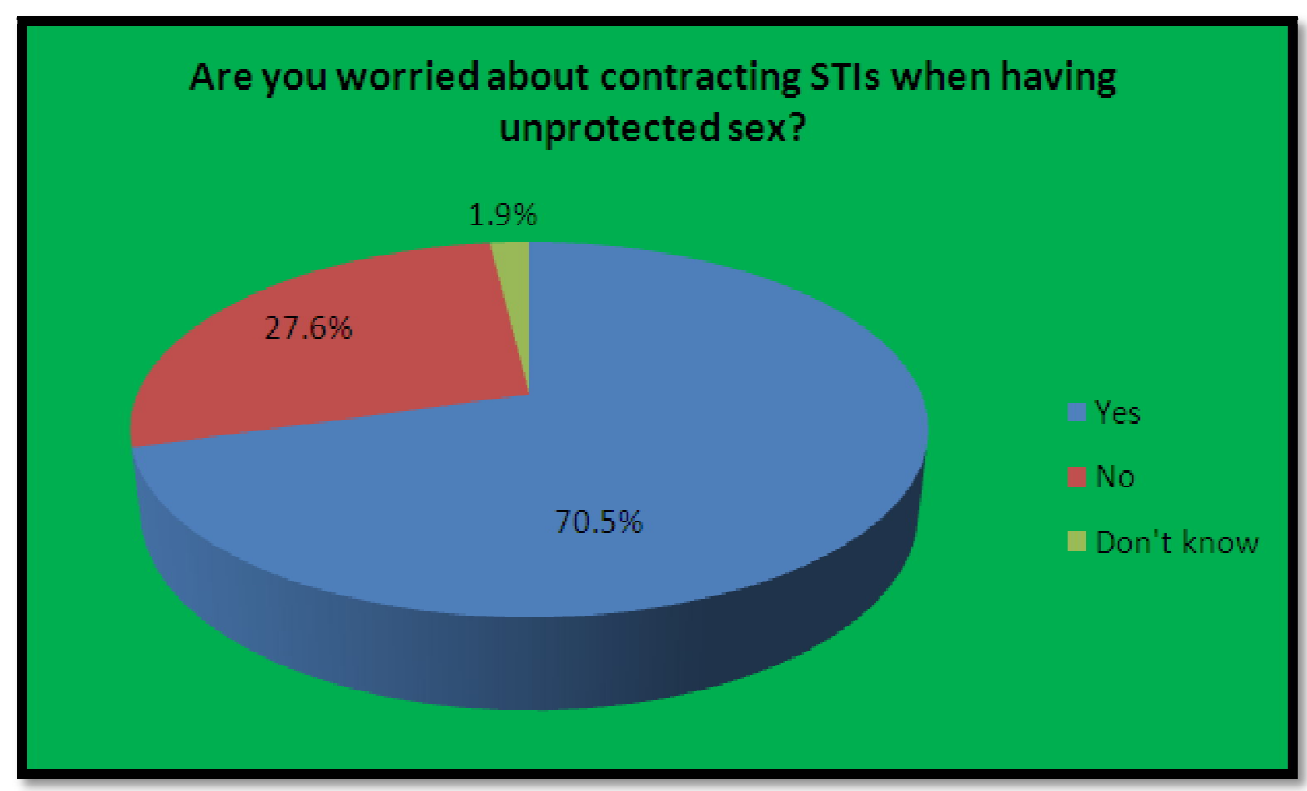

Figure 4: Respondents' Views about Contracting STIs When Having Unprotected Sex

Contracting STIs when having unprotected sex was not the only worrisome thought on the minds of the respondents. In fact, getting STIs (including HIV/ AIDS) was not what the respondents feared the most when having unprotected sex. As seen in Fig. 5, pregnancy (54.3\%) was the most feared repercussion of having unprotected sex. Getting HIV infection accounted for $43.5 \%$. 


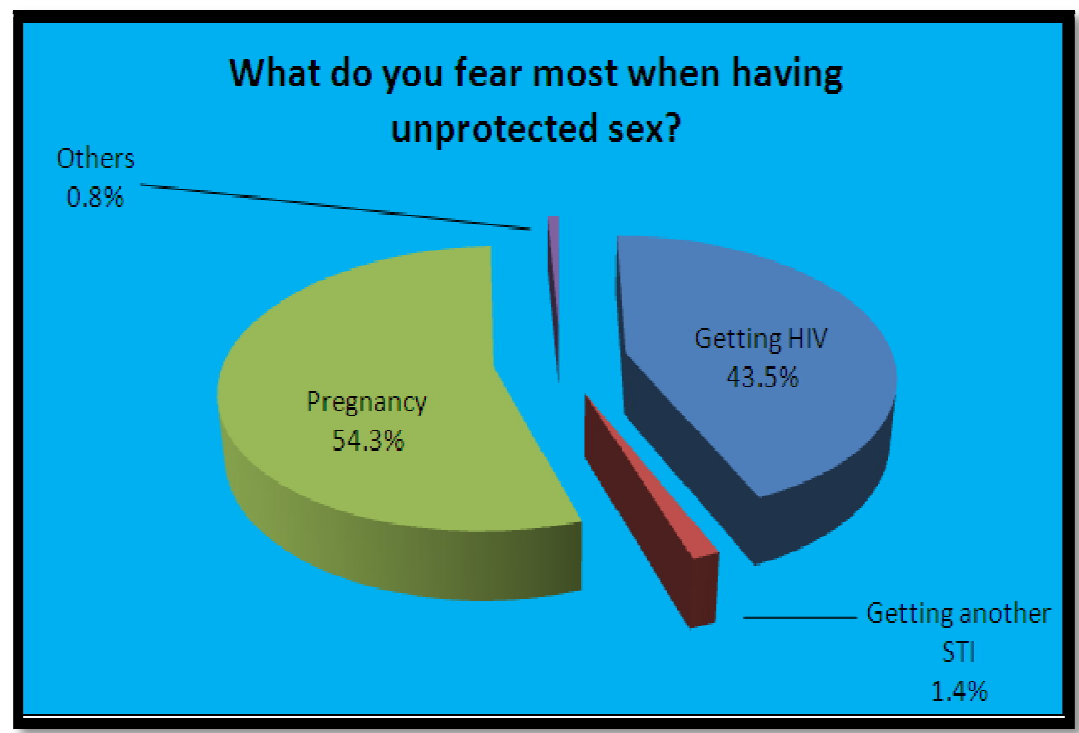

Figure 5: Respondents' Biggest Fear When Having Unprotected Sex

When asked what respondents felt for persons having STIs, pity $(72.4 \%)$ was the most commonly reported response (Fig. 6). Anger (8.6\%), disgust (8.1\%), and disappointment (10\%) were still reported by some of the respondents.

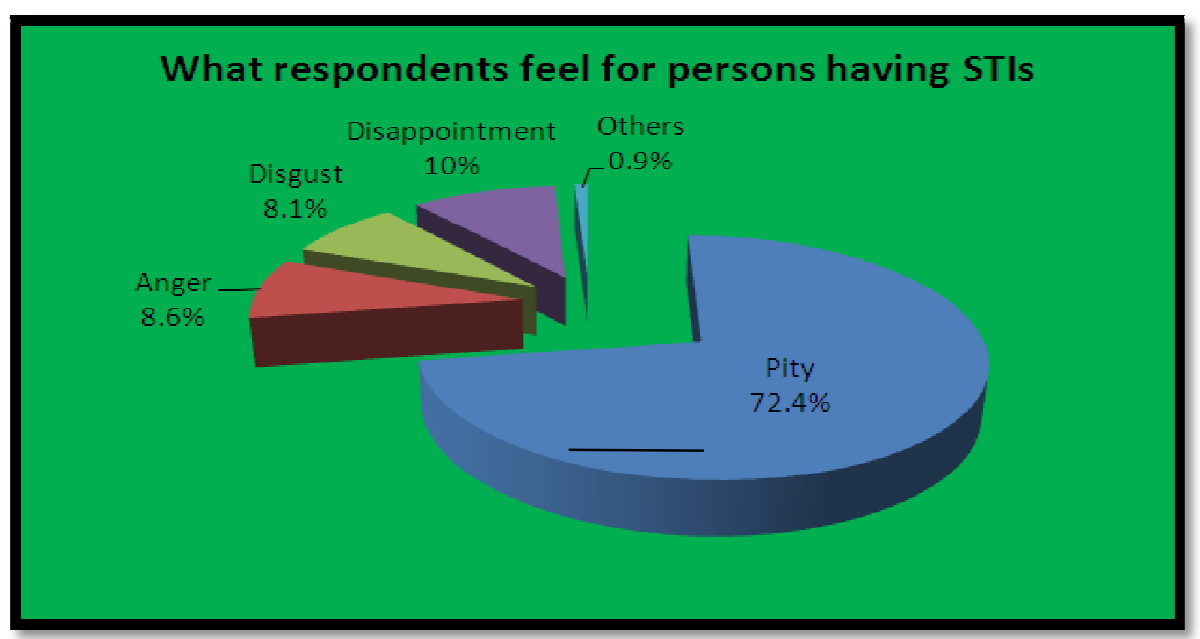

Figure 6: What Respondents Feel for Persons Having STIs

It is common knowledge that people with STIs (especially HIV/ AIDS) tend to be isolated from society. An overwhelming majority of the students who participated in this study (84.1\%) condemned this practice (Fig. 7). However, 51 respondents (13.8\%) held on to the belief that persons with STIs should be isolated from society.

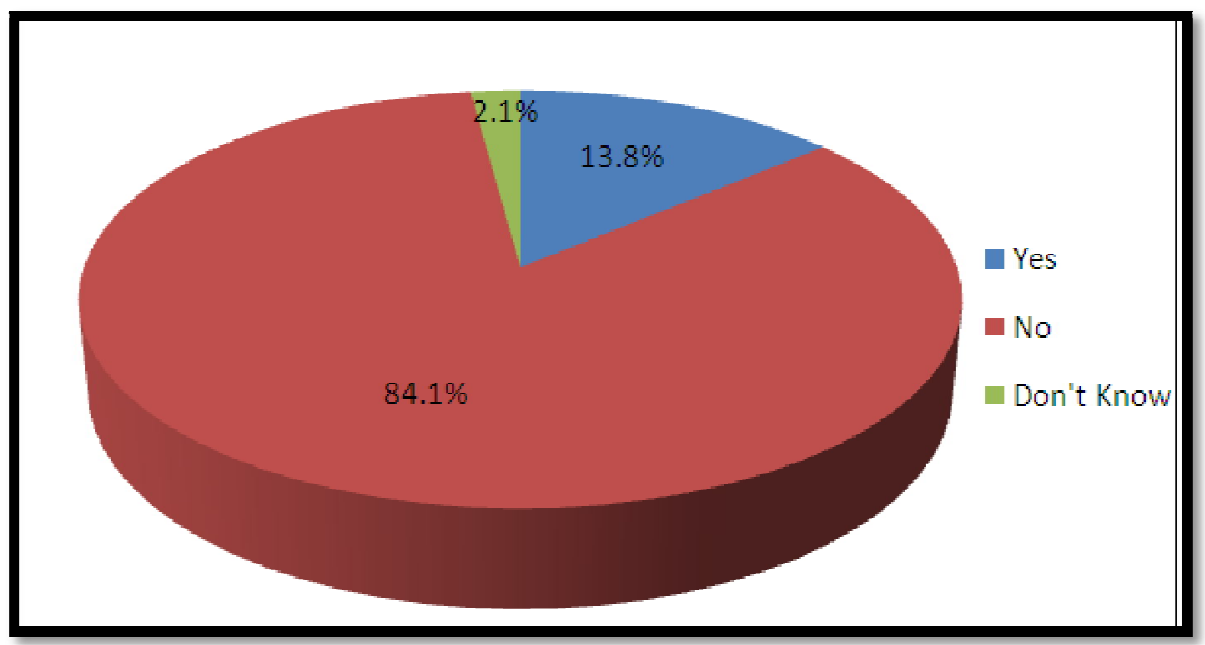

Figure 7: Respondents' Views about Isolating People with STI from Society 
Out of 370 respondents, 308 (83.2\%) said they would be willing to touch persons diagnosed with STIs, so long as the disease in question was not HIV/ AIDS (Fig. 8). A significantly lower number (242, corresponding to 65.4\%) had no problems touching people diagnosed with HIV/ AIDS.

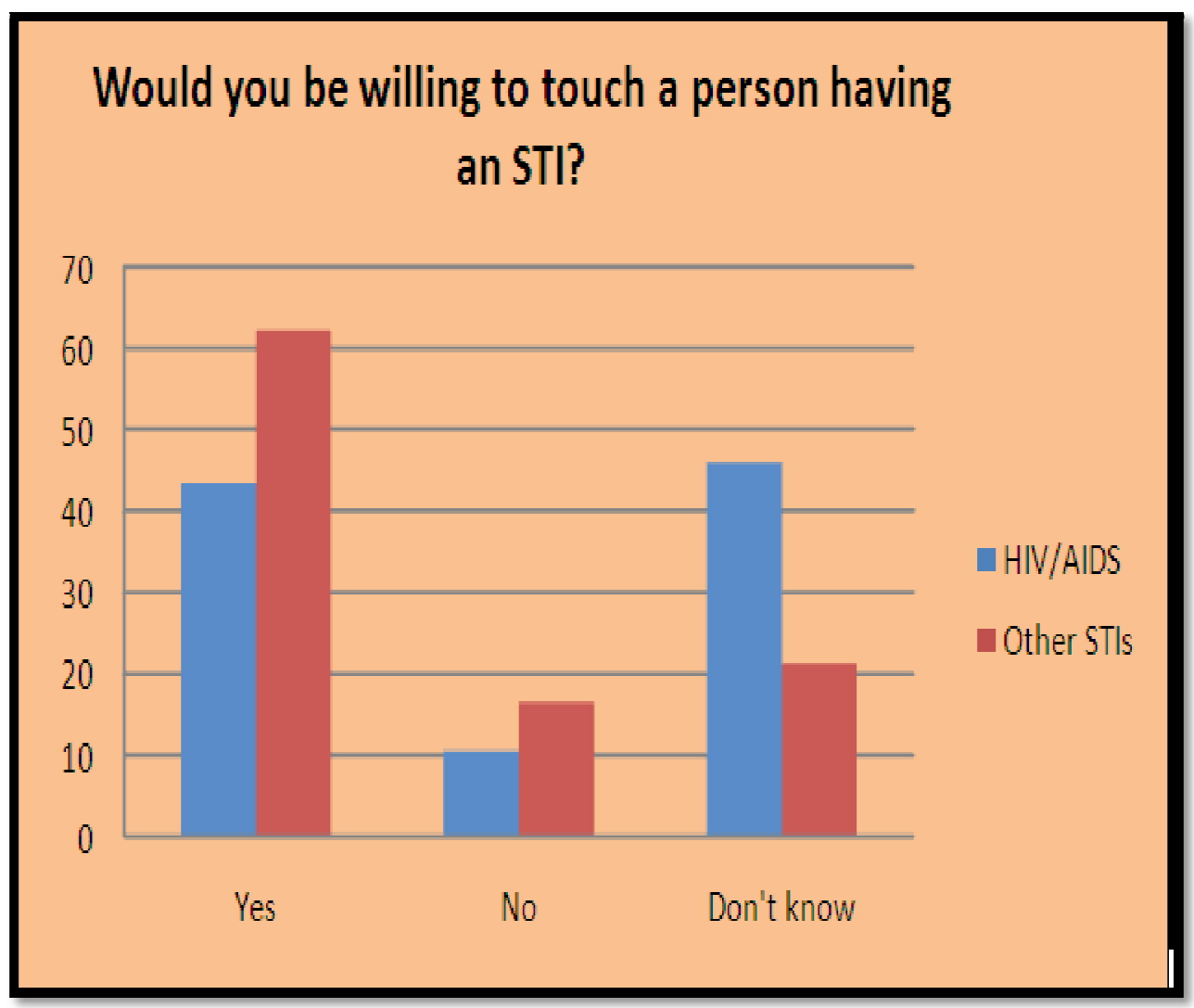

Figure 8: Respondents' Willingness to Touch a Person Having an STI

While majority of respondents expressed willingness to touch persons diagnosed with STIs, a far less number entertained the thought of living with the affected persons. As expected, the case was worse with persons diagnosed with HIV/ AIDS. Only 16 respondents (4.3\%) said they would be willing to live with persons having HIV/ AIDS (Fig. 9). As many as 251 respondents (67.8\%) would be willing to live with persons diagnosed with other STIs, certainly not HIV/ AIDS.

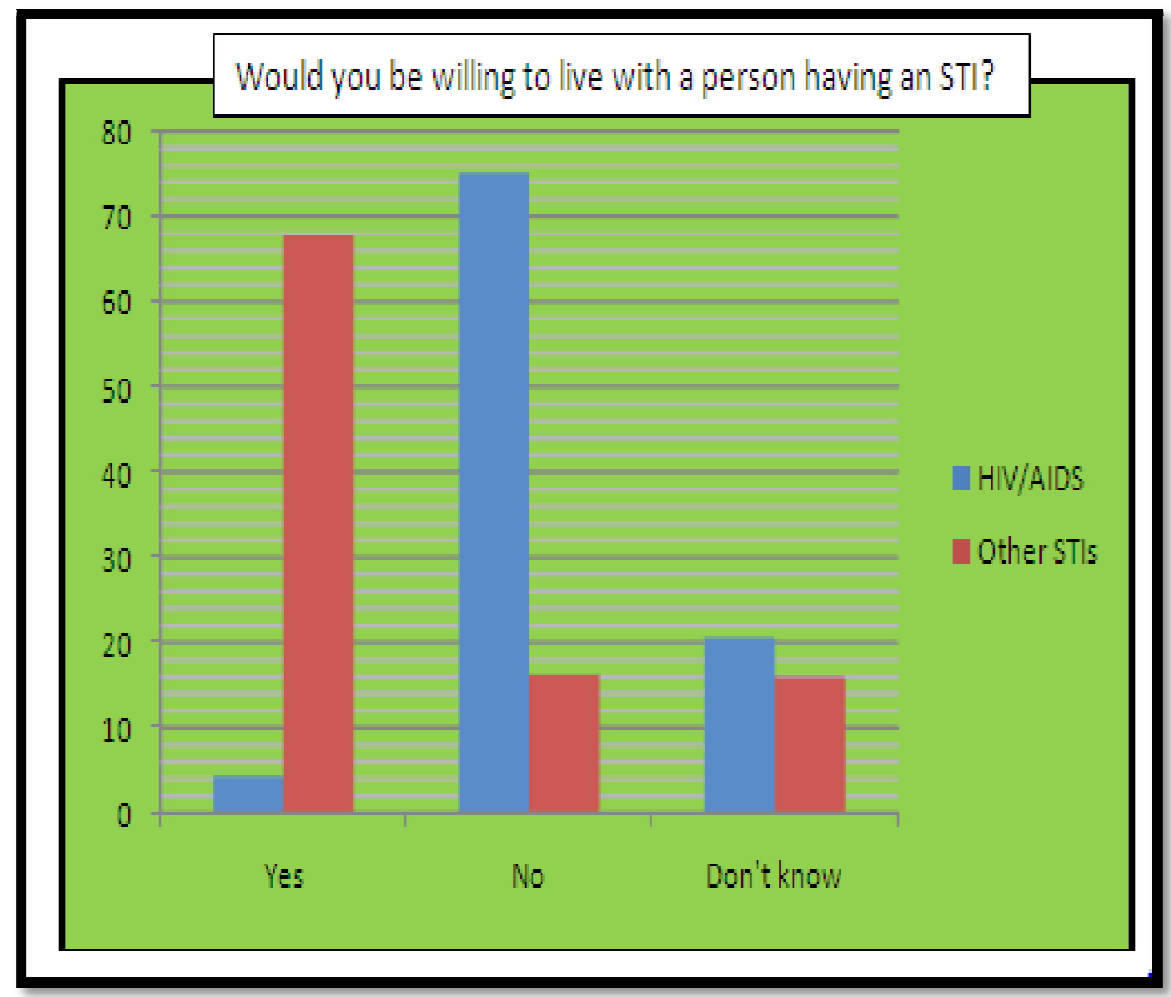

Figure 9: Respondents' Willingness to Live with a Person Having an STI 
Slightly more than half of the respondents (53.5\%) expressed willingness to share kitchen utensils with persons having STIs (other than HIV/ AIDS) (see Fig. 10). Less than half (41.9\%) did not mind sharing kitchen utensils with persons diagnosed with HIV/ AIDS.

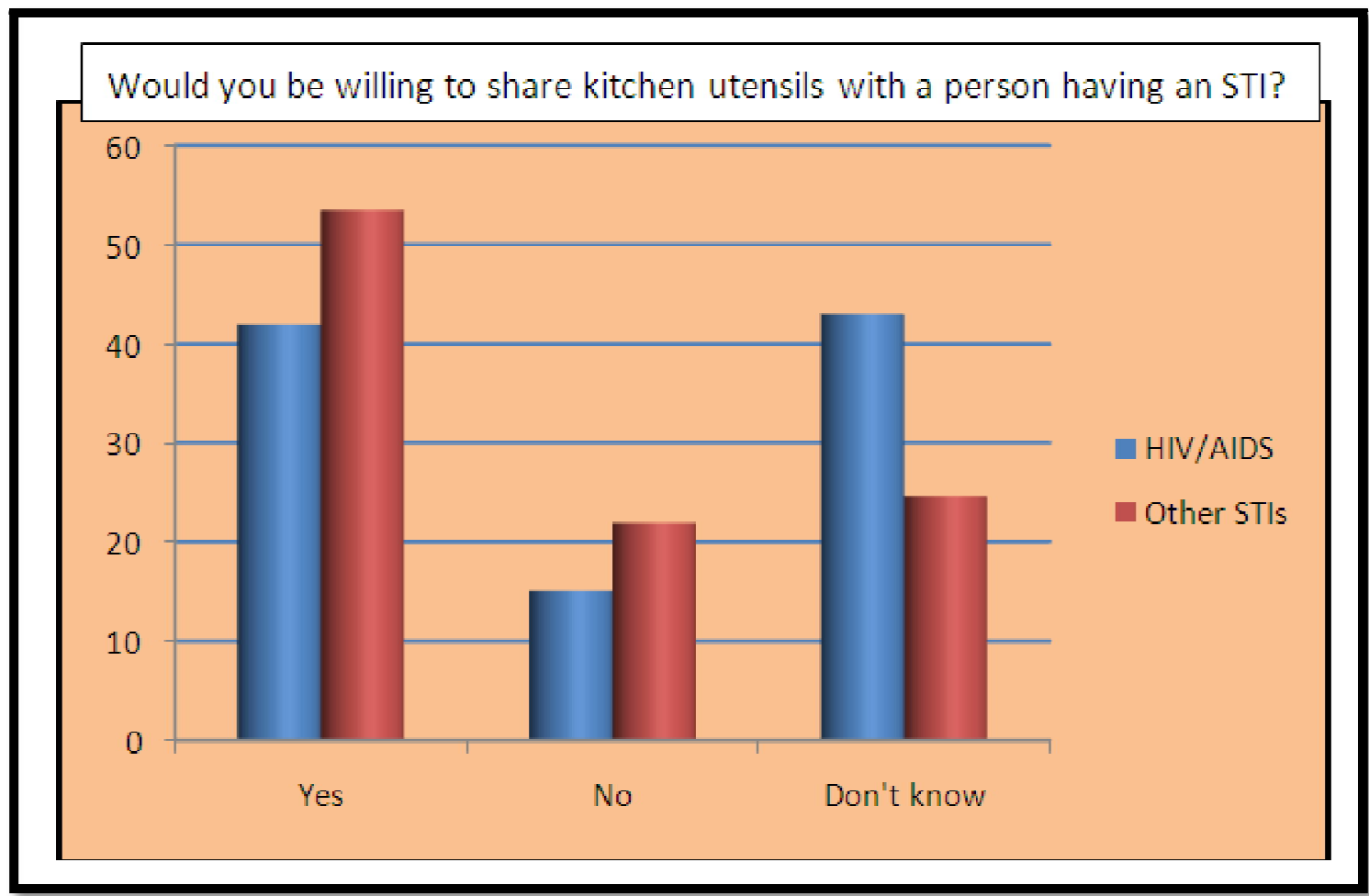

Figure 10: Respondents' Willingness to Share Kitchen Utensils with a Person Having an STI

While as many as $63.8 \%$ of respondents would share food with persons having other STIs, only $38.9 \%$ were willing to eat from the same plate with those diagnosed with HIV/ AIDS (Fig. 11).

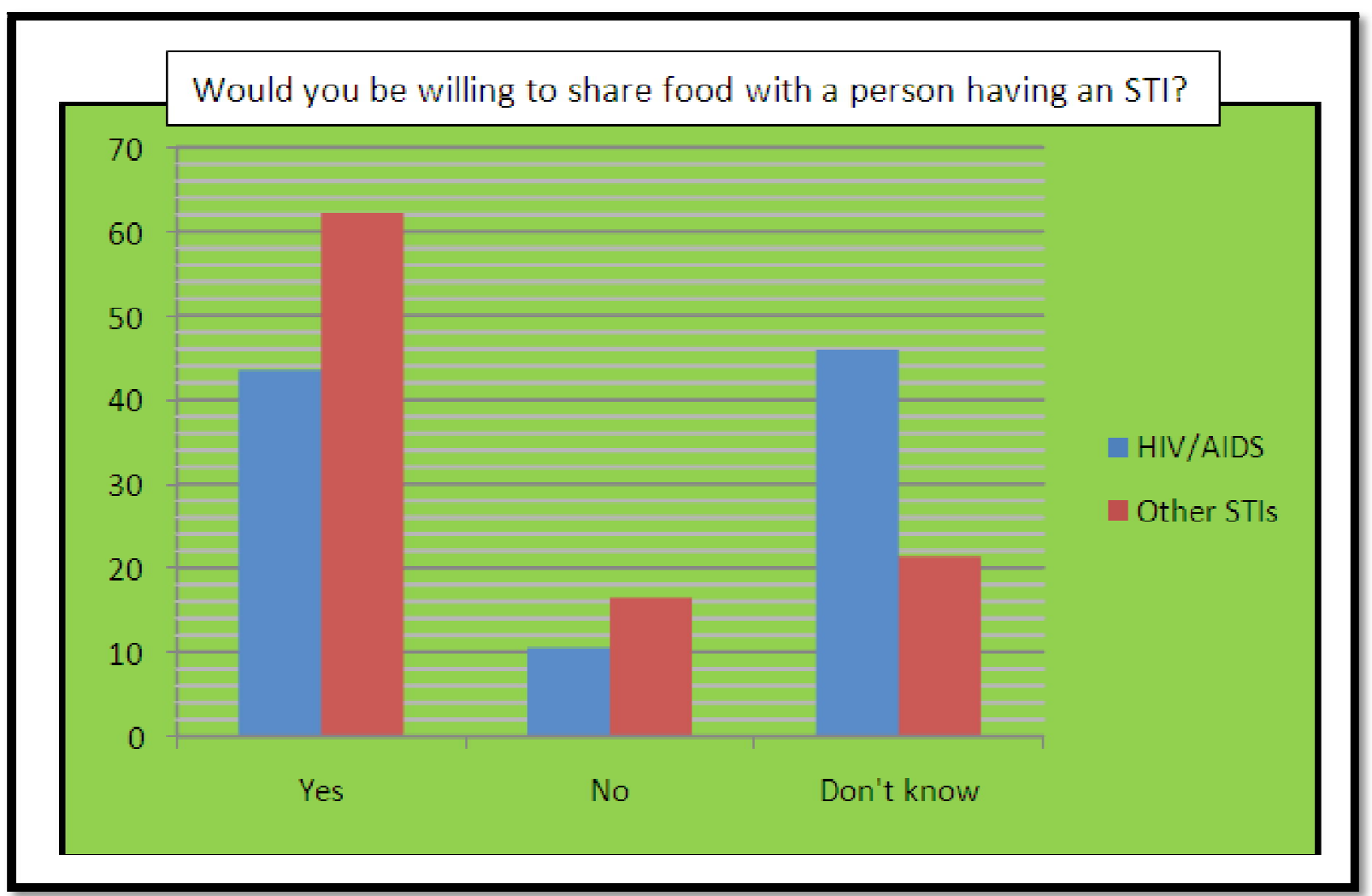

Figure 11: Respondents' Willingness to Share Food with a Person Having an STI

Following the same pattern, respondents would be willing to share swimming pool with persons having STIs provided that the medical condition concerned is not HIV/ AIDS. $62.2 \%$ of respondents would share swimming pool with persons having STIs other than HIV/ AIDS (Fig. 12). 


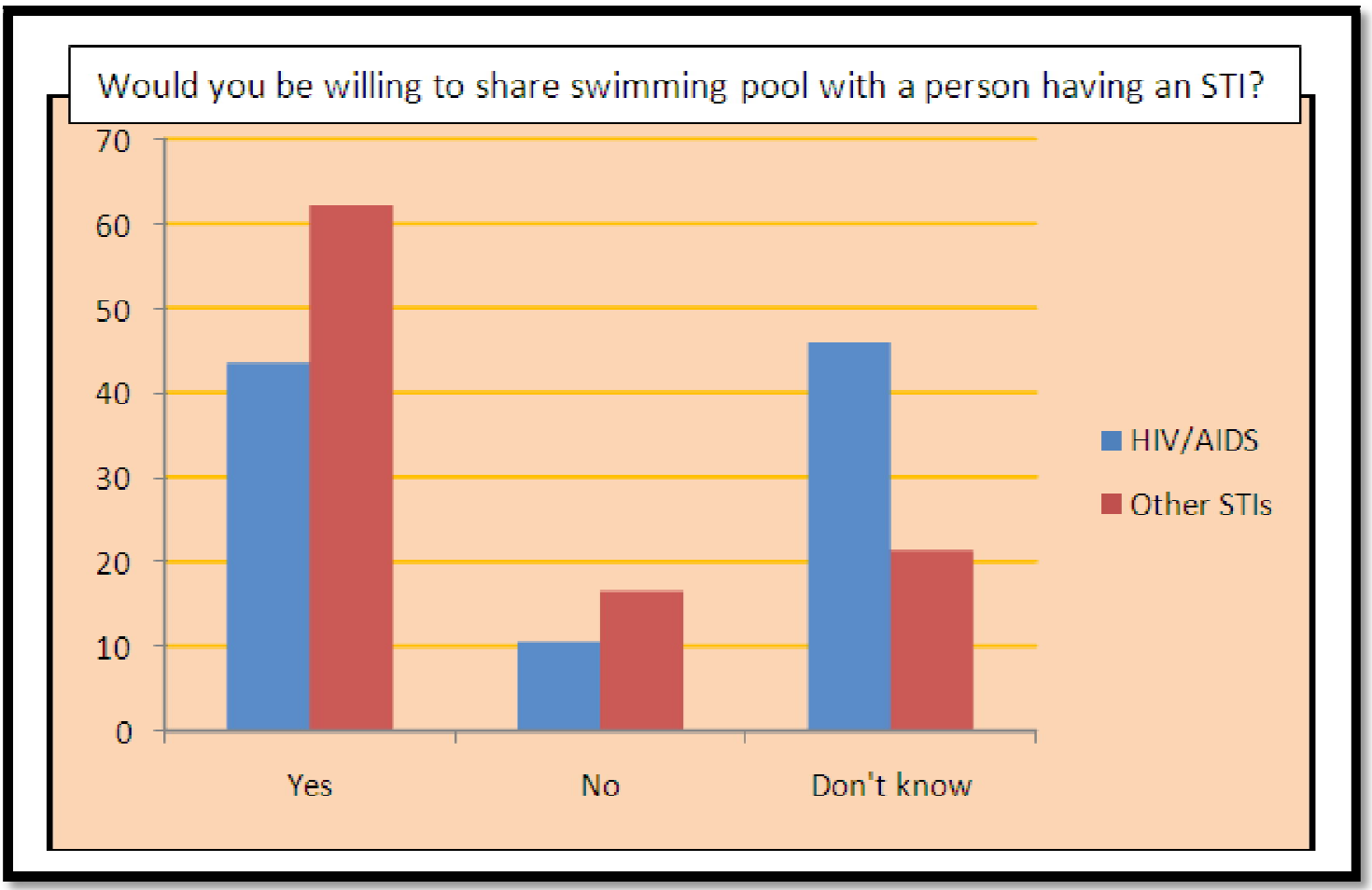

Figure 12: Respondents' Willingness to Share Swimming Pool with a Person Having an STI

When the respondents were asked if they would be willing to get tested for STIs (including HIV/ AIDS), most of them (81.9\%) replied in the affirmative (Fig. 13). $8.1 \%$ would not get tested, while the other $10 \%$ were undecided.

\section{Would you be willing to get tested for STIs?}

\section{Yes No Don't know}
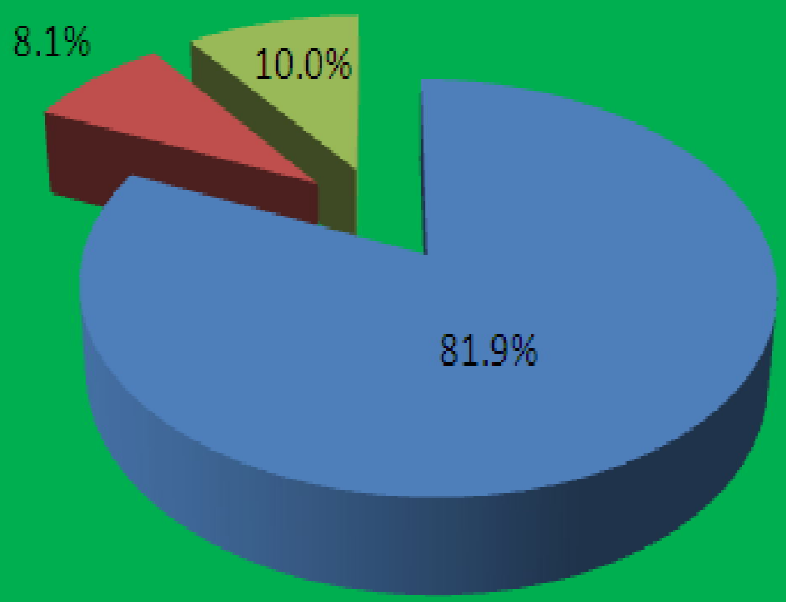

Figure 13: Respondents' Willingness to Get Tested for STIs

In a similar development, majority of the respondents (94.1\%) would love to have their partners tested for STIs before marriage (Fig. 14). 5.1\% did not see the need to subject their partners to the test, while the remaining $0.8 \%$ were undecided. 


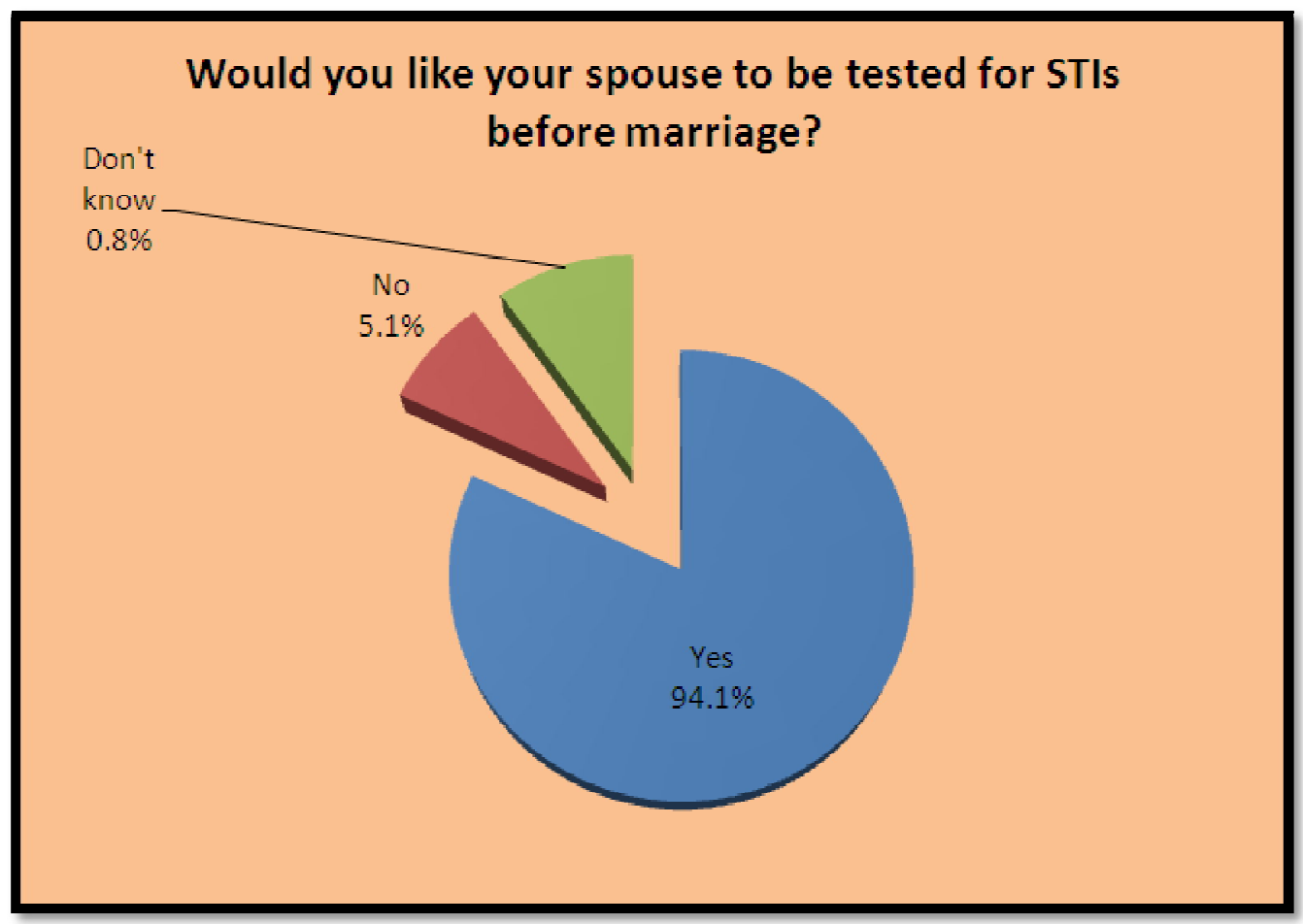

Figure 14: Respondents' Desire to Get Spouse Tested for STIs before Marriage

Respondents were asked where they would choose to present themselves for STI testing, having previously acknowledged the various options. An overwhelming majority (61.9\%) opted for the private laboratory (Fig. 15). Coming a distant second was the private hospital (16.2\%), while the STI clinic was third on the list (14.6\%).

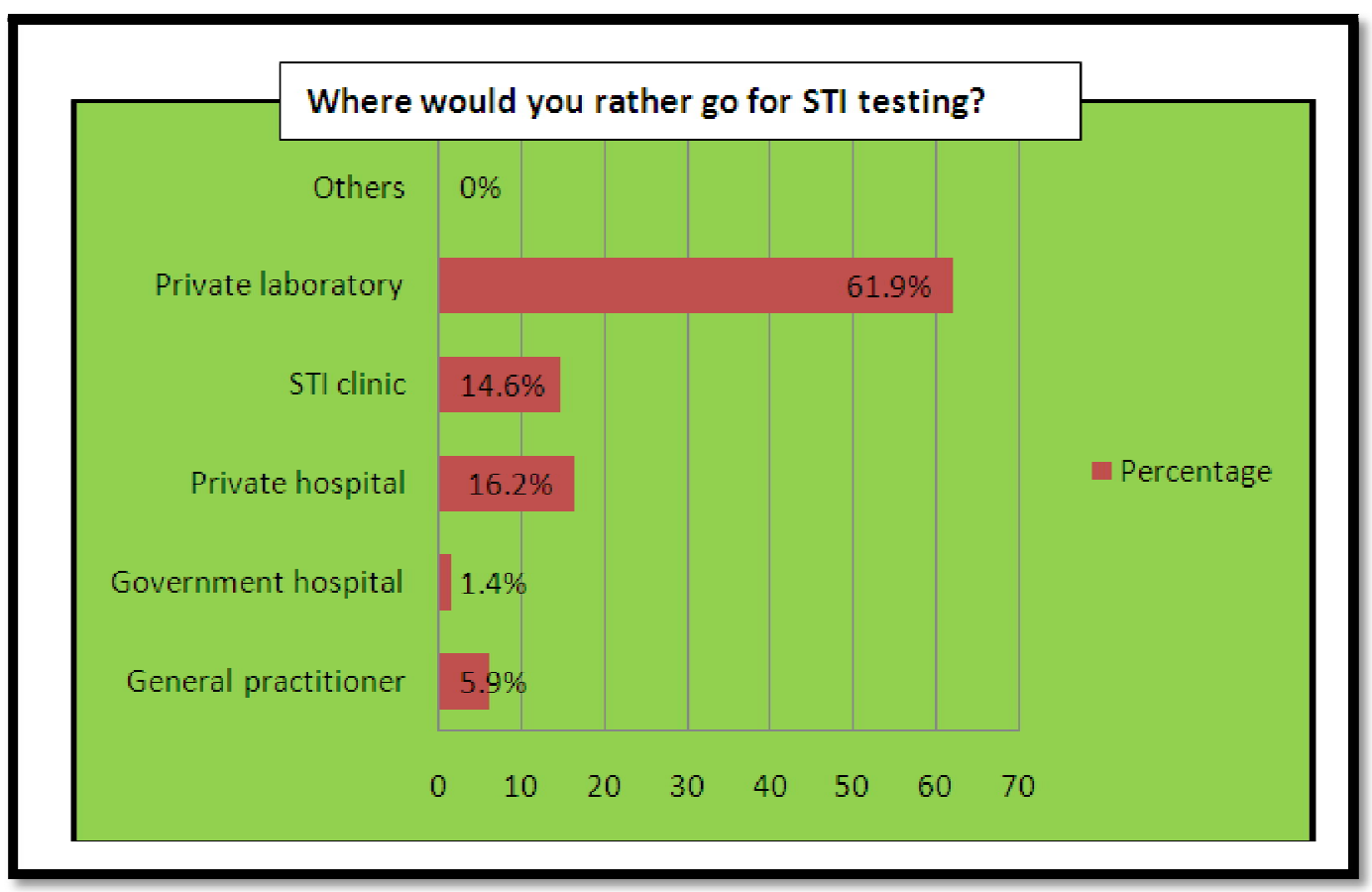

Figure 15: Most Likely Destination for STI Testing

In the same vein, respondents were asked to identify where they would rather go for treatment if tested positive for one or more STIs. Private hospital (35.9\%) was the preferred destination (Fig. 16), followed by STI clinic (22.7\%) and Government hospital (21.6\%). It is disturbing to note that some respondents $(10.8 \%)$ would still choose to visit the Traditional healer for STI treatment, while another $2.2 \%$ would opt for Self-medication. 


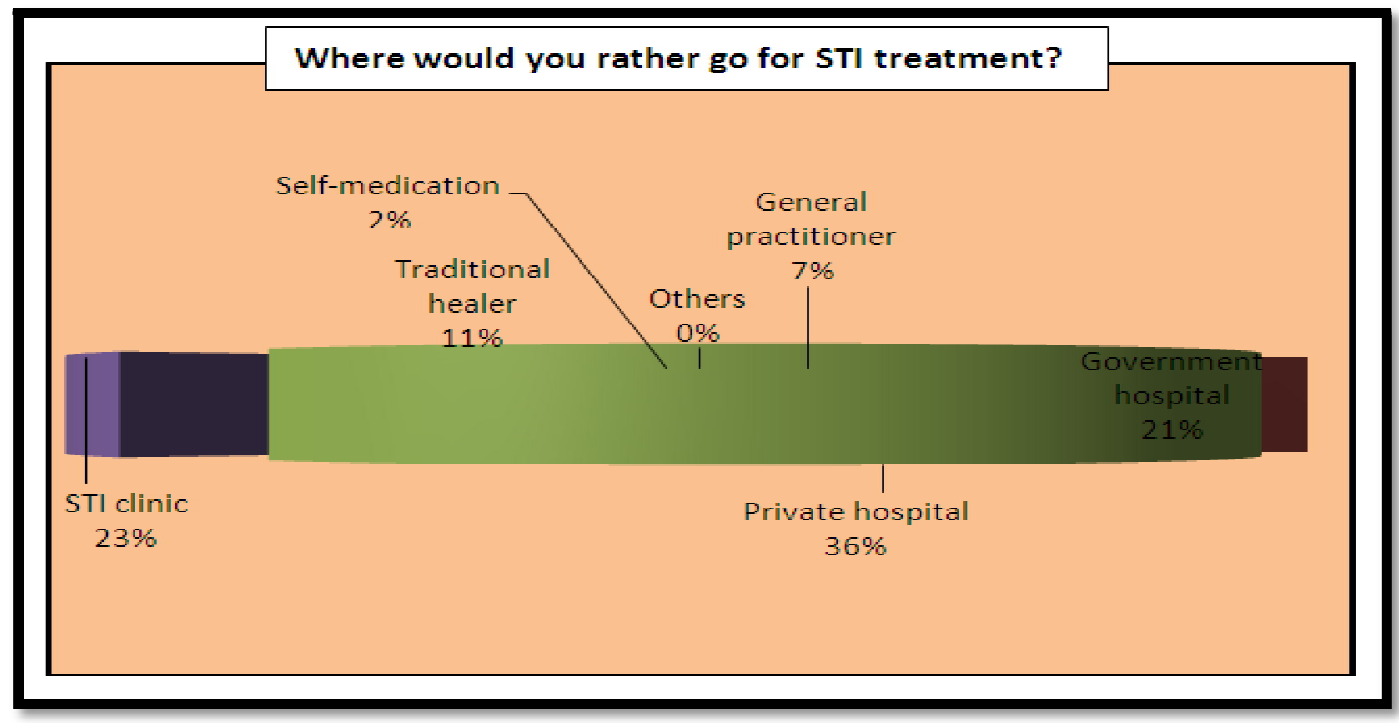

Figure 16: Most Likely Option/ Destination for STI Treatment

When the respondents were asked what they felt about the need for young people to get information about STIs, all of them $(100 \%)$ said it was absolutely necessary.

\subsection{Practices Regarding STIs}

84.1\% of the students in this study admitted to have had sex before, while $15.9 \%$ said they had not (Table 18). $77.8 \%$ of the students had had sex within the last three months, while $22.2 \%$ had not (see Table 19).

\begin{tabular}{|c|c|c|}
\hline \multirow{2}{*}{ Responses } & \multicolumn{2}{|c|}{ History of Sexual Encounter } \\
\cline { 2 - 3 } & Frequency & Percentage (\%) \\
\hline Yes & 311 & 84.1 \\
\hline No & 59 & 15.9 \\
\hline Total & 370 & 100 \\
\hline
\end{tabular}

Table 18: Number of Respondents Who Have Had Sex Before

\begin{tabular}{|c|c|c|}
\hline \multirow{2}{*}{ Responses } & Sexual Encounter within Last Three (3) Months \\
\cline { 2 - 3 } & Frequency & Percentage (\%) \\
\hline Yes & 288 & 77.8 \\
\hline No & 82 & 22.2 \\
\hline Total & 370 & 100 \\
\hline
\end{tabular}

Table 19: Number of Respondents Who Have Had

Sex within the Last 3 Months

Among the students who participated in this study, 32.7\% had their first sexual encounter before their fifteenth birthday (see Fig. 17). 30.5\% were not up to 18 years when they had sex for the first time. 16.5\% had their first sex when they were barely 20 years old. Only $2.7 \%$ said they were above 20 years when they first had sex.

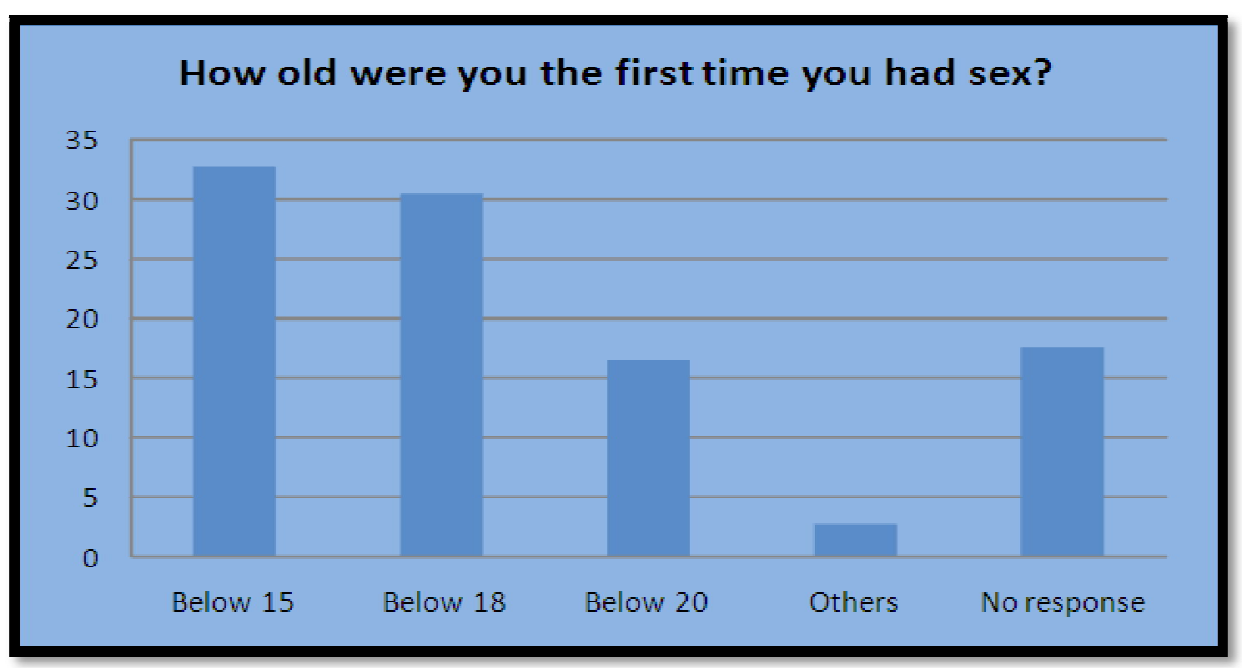

Figure 17: Bar Chart Showing Respondents' Age of Onset of First Sexual Encounter 
When the students were asked how frequent they had sex, the most common response was 'once a week' (22.4\%), followed closely by 'once in a while' (20.3\%). $17.3 \%$ had sex at least three times a week, while $9.7 \%$ had sex every other day (Table 20).

\begin{tabular}{|c|c|c|}
\hline \multirow{2}{*}{ Responses } & \multicolumn{2}{|c|}{ Regularity of Sexual Encounters } \\
\cline { 2 - 3 } & Frequency & Percentage (\%) \\
\hline Everyday & 36 & 9.7 \\
\hline At least 3 times a week & 64 & 17.3 \\
\hline Once a week & 83 & 22.4 \\
\hline Once in a while & 75 & 20.3 \\
\hline Others & 47 & 12.7 \\
\hline No response & 65 & 17.6 \\
\hline Total & 370 & 100 \\
\hline
\end{tabular}

Table 20: Regularity of Sexual Encounters among the Respondents

$74.9 \%$ of the students had multiple sex partners, while $25.1 \%$ said they had not (Table 25). A slight majority of the students (28.1\%) had 4 or more sexual partners (see Fig. 18). 22.2\% had 3,17.3\% had 2,16.5\% had only 1 sex partner and $15.9 \%$ had none at all.

\begin{tabular}{|c|c|c|}
\hline \multirow{2}{*}{ Responses } & \multicolumn{2}{|c|}{ Involvement in Multiple Sexual Partnerships } \\
\cline { 2 - 3 } & Frequency & Percentage (\%) \\
\hline Yes & 277 & 74.9 \\
\hline No & 93 & 25.1 \\
\hline Total & 370 & 100 \\
\hline \multicolumn{2}{|c|}{ Table 21: Involvement in Multiple Sexual Partnerships } \\
\hline
\end{tabular}

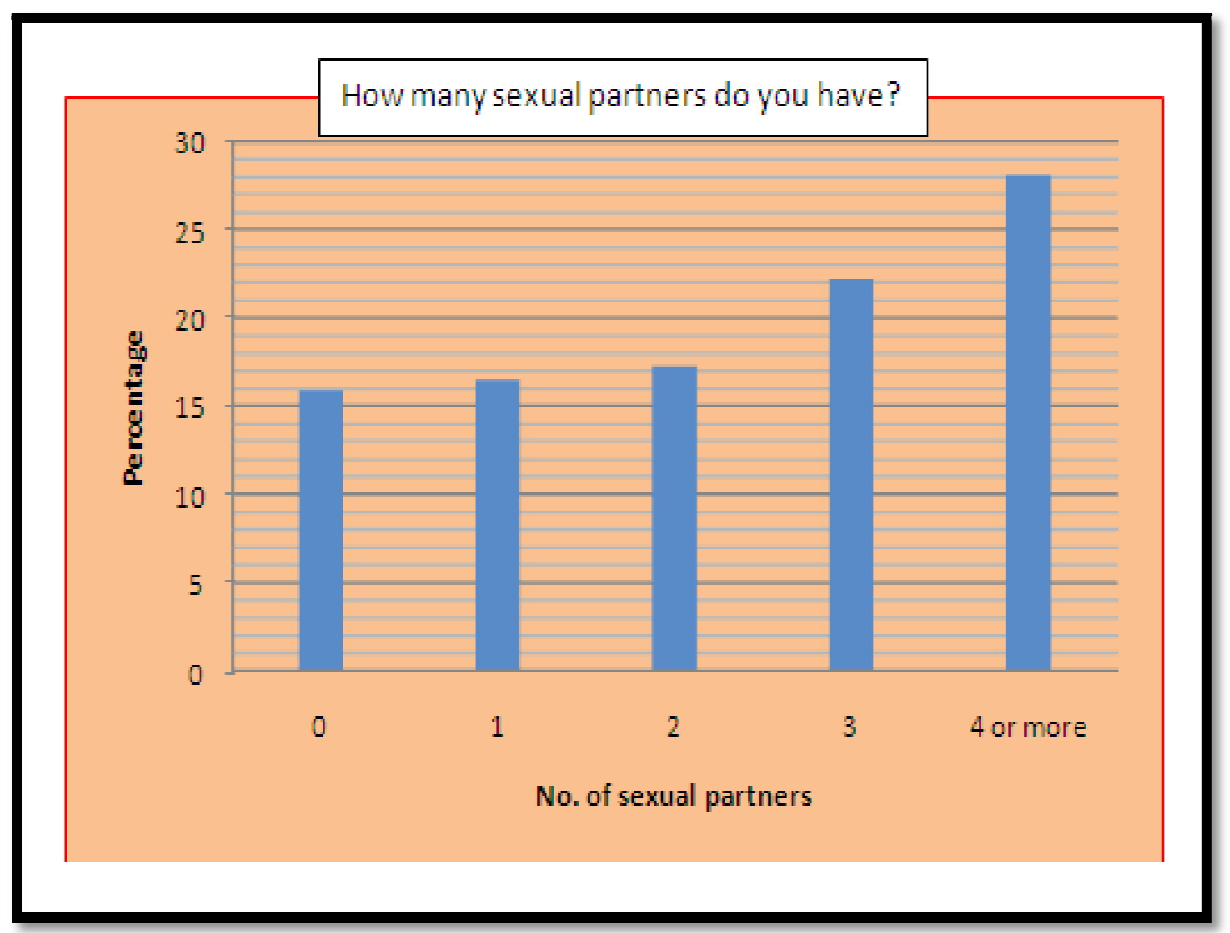

Figure 18: Bar Chart Showing Number of Sex Partners Respondents Have

$21.1 \%$ of the students chose not to answer the question on the use of condoms. $45.4 \%$ said they 'sometimes' use condoms, 18.9\% claimed they 'always' used condoms, while $14.6 \%$ admitted to 'never' using condoms during sexual activity (Fig. 19). 


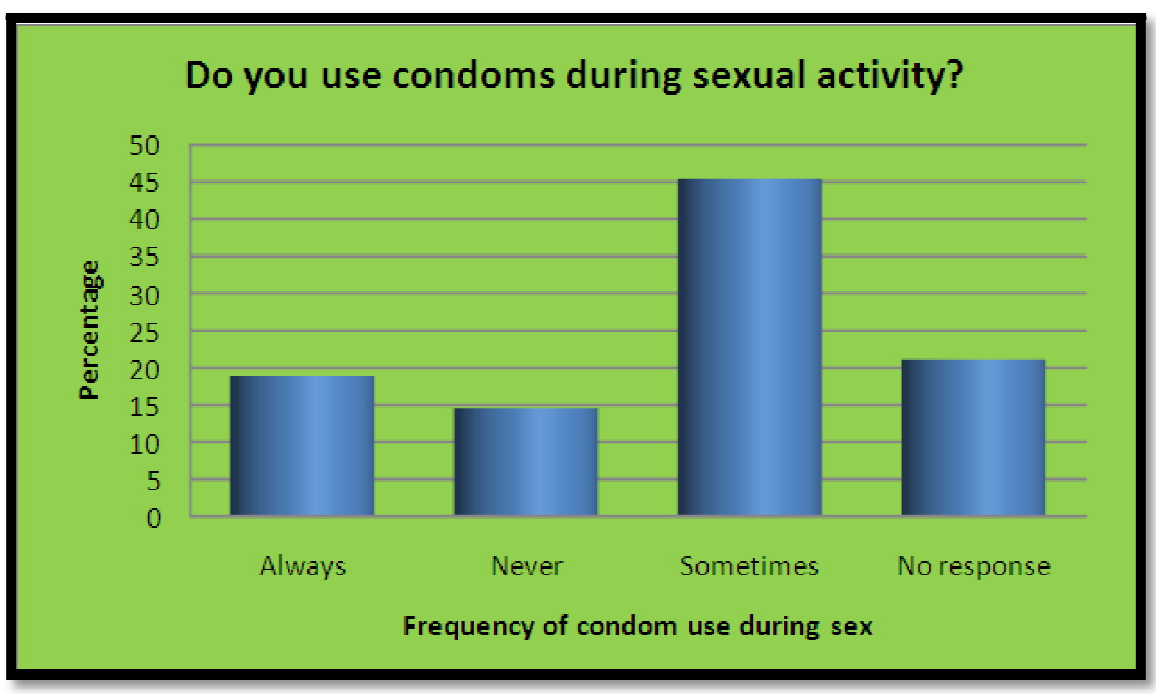

Figure 19: Bar Chart Showing Number of Respondents Who Use Condoms during Sex

Respondents were asked to provide reasons for not using condoms during sex. Majority (37.3\%) did not provide any response. Among those who responded, 16.2\% said it was for 'more sexual satisfaction' (see Table 22), while $13.2 \%$ said it was 'for fun (adventure)'. 9.5\% had unprotected sex because they wanted to 'compare with condom use'. $6.8 \%$ claimed they were bowing to 'peer pressure'. Interestingly, $12.4 \%$ said they were sure their body systems and those of their partners were free of STIs, hence there was no need using condoms. Another $4.6 \%$ said they had unprotected sex because they were afraid of certain 'myths surrounding use of condoms'.

\begin{tabular}{|c|c|c|}
\hline \multirow{2}{*}{ Responses } & \multicolumn{2}{|c|}{ Reasons for having Unprotected sex } \\
\cline { 2 - 3 } & Frequency & Percentage $(\%)$ \\
\hline For fun (adventure) & 49 & 13.2 \\
\hline Peer pressure & 25 & 6.8 \\
\hline More sexual satisfaction & 60 & 16.2 \\
\hline For comparison with condom use & 35 & 9.5 \\
\hline Neither me nor my partner has an STI & 46 & 12.4 \\
\hline Myths surrounding use of condoms & 17 & 4.6 \\
\hline No response & 138 & 37.3 \\
\hline Total & 370 & 100 \\
\hline
\end{tabular}

Table 22: Why Respondents Have Unprotected Sex

The students in this study were asked if they use pornographic materials (x-rated internet sites, adult movies, adult magazines, etc). As many as 78.9\% admitted that they do (Fig. 20). 45.9\% also admitted to using alcohol and/ or other hard drugs before sex (Fig. 21), while 25.1\% had had sex with commercial sex workers (Fig. 22).

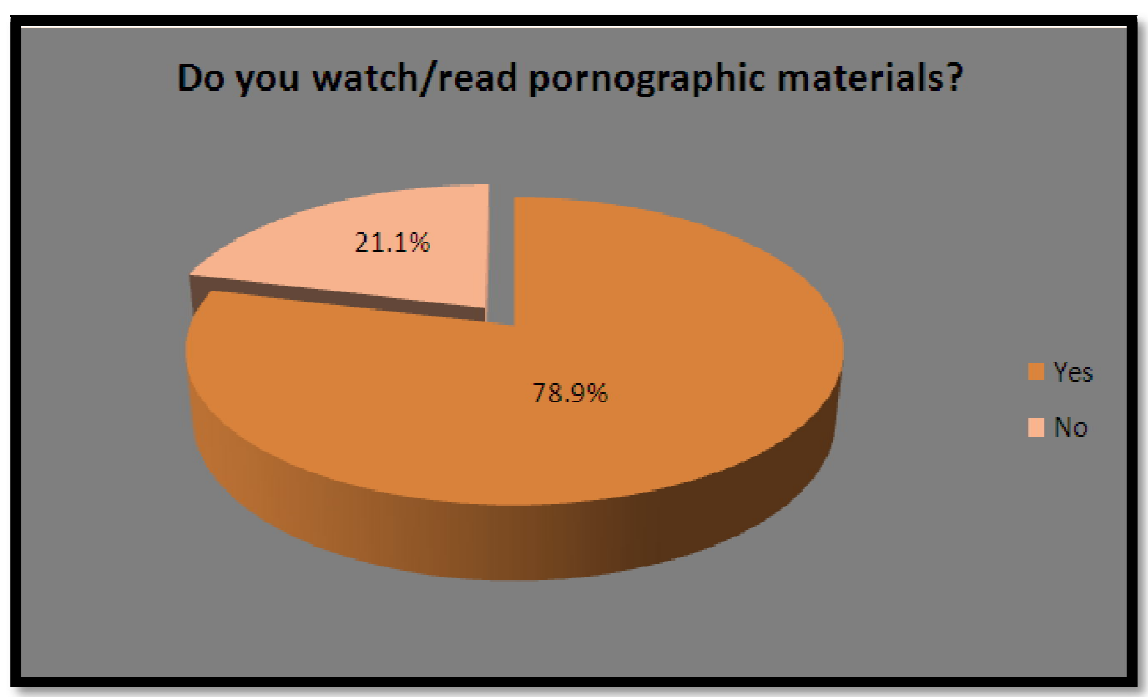

Figure 20: Pie Chart Showing Number of Respondents Who Use Pornographic Materials 


\section{Do you take alcohol and/or other hard drugs before having sex? \\ Yes No}

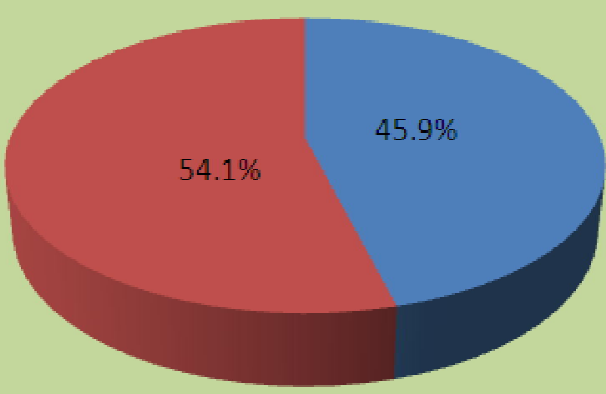

Figure 21: Pie Chart Showing Number of Respondents Who Use Alcohol and/ or Other Hard Drugs before Sex

Have you had sex with commercial sex workers?

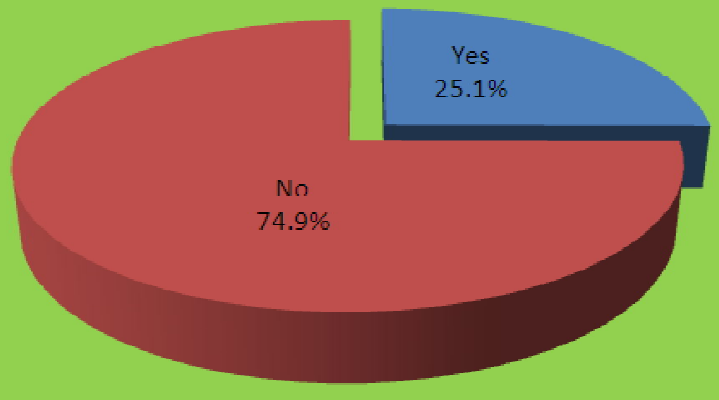

Figure 22: Pie Chart Showing Number of Respondents Who Have Had Sex with Commercial Sex Workers

Only $44.3 \%$ of the students said they had been tested for HIV (Table 23). A larger number (66.8\%) said they had been tested for other STIs (Table 24). 55.4\% revealed they had been diagnosed with at least one STI (Table 25).

\begin{tabular}{|c|c|c|}
\hline \multirow{2}{*}{ Responses } & \multicolumn{2}{|c|}{ HIVTesting among Respondents } \\
\cline { 2 - 3 } & Frequency & Percentage (\%) \\
\hline Yes & 164 & 44.3 \\
\hline No & 206 & 55.7 \\
\hline Total & 370 & 100 \\
\hline
\end{tabular}

Table 23: Number of Respondents Who Have Been Tested for HIV

\begin{tabular}{|c|c|c|}
\hline \multirow{2}{*}{ Responses } & \multicolumn{2}{|c|}{ Respondents Tested for Other Stis } \\
\cline { 2 - 3 } & Frequency & Percentage (\%) \\
\hline Yes & 247 & 66.8 \\
\hline No & 123 & 33.2 \\
\hline Total & 370 & 100 \\
\hline
\end{tabular}

Table 24: Number of Respondents Who Have Been Tested for Other STIS

\begin{tabular}{|c|c|c|}
\hline \multirow{2}{*}{ Responses } & \multicolumn{2}{|c|}{ Respondents Diagnosed with an STI } \\
\cline { 2 - 3 } & Frequency & Percentage (\%) \\
\hline Yes & 205 & 55.4 \\
\hline No & 165 & 44.6 \\
\hline Total & 370 & 100 \\
\hline \multicolumn{2}{|c|}{ Table 25: Number of Respondents Who Have Been Diagnosed with at Least One STI }
\end{tabular}




\section{Discussions}

\subsection{Knowledge of Respondents about STIs}

All the students who participated in this study (100\%) had heard about HIV/ AIDS. This result matches the 100\% recorded among undergraduate students in Benin City, southern Nigeria ${ }^{20}$ as well as in a Kenyan university ${ }^{21}$. Similar studies have reported lower HIV/ AIDS knowledge levels among undergraduate students. Lower knowledge levels (82\%) have been reported in the United States 22 , and even lower (70\%) in Cameroun ${ }^{23} .67 \%$ was recorded in Zaria, northern Nigeria 24 , but as high as $92.4 \%$ was recorded in Ado Ekiti, southwestern Nigeria ${ }^{25} .98 \%$ was recorded in Abeokuta, western Nigeria ${ }^{7} .89 \%$ was recorded in Uganda ${ }^{26}, 92 \%$ in Malaysia ${ }^{27}$, 99\% in Wuhan (China) ${ }^{28}$, and 99.5\% in northern Thailand 29 .

Even though all the students (100\%) who took part in this research had heard about HIV/ AIDS, not all of them knew what the acronym stood for. In fact, only about two-thirds (66.2\%) knew the full meaning of HIV/ AIDS. This buttresses the need to commence sexual health education at an early age $30,31,6,32$, among other interventions.

Apart from HIV/ AIDS, most of the respondents knew of the existence of other STIs like gonorrhoea, chlamydia, trichomoniasis, genital warts, genital herpes, hepatitis B and syphilis. Gonorrhoea (96.8\%) and syphilis (91.6\%) were the most common STIs known by the $91.4 \%$ respondents, while trichomoniasis $(29.5 \%)$ and chlamydia $(31.1 \%)$ were the least known. These results are in conformity with findings from similar studies in Ogun State, Nigeria 33 , where awareness levels of gonorrhoea and syphilis among respondents were reportedly higher in comparison to trichomoniasis and chlamydia.

This study sought to know the means through which respondents gained access to information regarding STIs. The internet was the highest source of knowledge (92.2\%) among the respondents. In a similar study among undergraduate students in the University of Abuja, Nigeria, the most frequently chosen source of STI information was the television, accounting for $82 \%{ }^{34}$. However, in Ethiopia and other parts of China, respondents relied far less on the television as the source of STI knowledge, with only $46.7 \%$ and $50.9 \%$ reporting their dependence on that source 28,35 .

Most of the respondents had a good knowledge of the basic routes of transmission of STIs. Unprotected sex $(93.2 \%)$ and blood transfusion (89.2\%) were the most commonly cited routes of STI transmission. Others were mother to unborn child (87.8\%) and sharing of sharp objects (81.1\%). However, there were some respondents who held on to a number of false, mistaken beliefs regarding routes of STI transmission. 82.4\% of the respondents believed STIs could be transmitted by sharing a toilet seat, $67.6 \%$ believed kissing was a route of STI transmission, $27.0 \%$ believed handshake was another route of transmission, while $20.3 \%$ believed witchcraft was a means through which STIs could be transmitted. These results are similar to those obtained by Amu \& Adegun 36 who found out that $22 \%$ of secondary school students in Ado Ekiti, southwestern Nigeria believed that STIs could be transmitted through coughing and sneezing. 16\% of these students believed STIs could be transmitted by sharing toilets, and another $12 \%$ believed sharing kitchen utensils (plates) was a route of STI transmission. Among undergraduate students in the University of Abuja, north-central Nigeria, 23.6\% believe STIs could be transmitted through kissing, witchcraft, sharing toilets, and sharing kitchen utensils ${ }^{34}$. In Ghana, witchcraft was a commonly cited route of STI transmission among youths, alongside kissing, handshake, sharing of clothes, kitchen utensils, food and beddings ${ }^{37}$.

The most common signs and symptoms of STIs (including HIV/ AIDS) reported by the respondents were weight loss (96.7\%), abdominal pain (92.7\%), genital discharge (88.4\%), skin rash (84.1\%) and recurrent fever (83.5\%). This result agrees with findings from Abuja, Nigeria ${ }^{34}$ where respondents reported weight loss as the most frequently known symptom among undergraduate students. However, skin rash was the most commonly reported symptom among refugees in Ogun State, Nigeria ${ }^{33}$. Weight loss and skin rash were reported more frequently among respondents in these studies because they are the most obvious symptoms of HIV/ AIDS38. A study in Uganda revealed that university students were more familiar with the symptoms of HIV/ AIDS compared to other STIs ${ }^{26}$. In Cameroun, as little as $16.1 \%$ of secondary school students could identify the symptoms of common STIs 39 . In India, about $67 \%$ of students were aware of the symptoms of STIs other than HIV/ AIDS (McManus \& Dhar, 2008)40.

The respondents displayed a relatively high level of awareness of STI preventive measures. Condom use (94.1\%) was the most frequently known preventive measure, followed by abstinence $(90.0 \%)$ and being faithful to one uninfected partner (84.6\%). The result is in tandem with that reported in a similar study in Uganda, where $93.5 \%$ of the respondents were aware of the condom as an STI preventive tool 26 . In Ghana, however, a lower number of respondents (78\%) reported condom use as an STI preventive measure ${ }^{41}$. Only $26 \%$ of students in this study knew that alcohol intake was associated with STIs. In Uganda, a greater number of university students (73\%) knew of the association between alcohol intake and the risk of contracting STIs 26 .

Majority of the students in this study were unaware of the complications of untreated STIs. Only $22.2 \%$ of the respondents knew that premature birth was a complication of untreated STIs. Knowledge levels were lower for infertility (21.1\%) and miscarriage (19.2\%). As much as $69.7 \%$ did not know that cervical cancer was a complication of untreated STIs. The results are similar (albeit lower in value) to those obtained from similar studies in Thailand where less than $50 \%$ of respondents knew about the complications of untreated STIs 29,42 .

A vast majority of the students (94.1\%) who participated in this study knew that STIs are treatable. While this was commendable, it was alarming to learn that $83.5 \%$ of the respondents believed there was an existing cure for all STIs, including HPV infection (genital warts), HSV infection (genital herpes) and HIV/ AIDS. This latter statistic probably explains why knowledge about complications of untreated STIs was remarkably low among the respondents. In Thailand, $95.6 \%$ of university students knew that STIs are treatable ${ }^{42}$. In Cameroun, $84 \%$ of secondary school students knew that most STIs can be cured 40 . 
When the respondents were asked if they knew where to go for STI testing (and possibly access treatment), majority were positive in their responses. However, 36 respondents $(0.9 \%)$ claimed they did not know that a General Practitioner could screen people for STIs (and possibly treat), whereas as many as 323 respondents (87.3\%) felt a Traditional healer could conduct STI testing (and carry out treatment).

Using Pearson's Chi-squared test for categorical data, no significant difference was observed between males and females regarding awareness levels of STIs ( $p=1.000$ for each of the eight STIs listed). Similar results were obtained in Thailand 42 and Vietnam ${ }^{43}$.

\subsection{Attitude of Respondents towards STIs}

Respondents were asked if they were worried about contracting STIs (including HIV/ AIDS) when having unprotected sexual intercourse. Majority (70.5\%) said they were worried. The results are similar to those obtained from qualitative studies in Ghana, where $70.9 \%$ of male students and $75 \%$ of female students admitted they were disturbed by the thought of STIs, especially HIV/ AIDS44.

Contracting STIs when having unprotected sex was not the only worrisome thought on the minds of the respondents. In fact, getting STIs (including HIV/ AIDS) was not what the respondents feared the most when having unprotected sex. Pregnancy (54.3\%) was the most feared repercussion of having unprotected sex. Thus, if respondents were to use condoms during sex, the main reason would be for the physical barrier to serve as a contraceptive tool. The result is in tandem with that obtained from a similar study in New Zealand, where young people were reported to be more troubled about preventing unwanted pregnancy than STIs ${ }^{45}$. Similar results were obtained in Thailand. In fact, getting an STI was the least popular choice among Thai university students ${ }^{42,46}$. In Malaysia, however, undergraduate students were more concerned about getting STIs (especially HIV) than having unwanted pregnancy ${ }^{47}$.

When asked what respondents felt for persons having STIs, pity $(72.4 \%)$ was the most commonly reported response. Disappointment (10\%), anger (8.6\%), and disgust (8.1\%) were still reported by some of the respondents. In the United States, $64 \%$ of males and $84 \%$ of females who attended the University of Washington knew someone who had contracted an STI, but only $36 \%$ of males and $26 \%$ of females felt pity for affected persons ${ }^{48}$. Many young adults in the Republic of Ireland believe people having STIs often get their social identities discredited by their partners or peers ${ }^{49}$.

Majority of the students who participated in this study (84.1\%) condemned the practice of isolating people who have been diagnosed with STIs. However, $13.8 \%$ held on to the belief that persons with STIs should be isolated from society. In the United States, $98 \%$ of male university students and $96 \%$ of their female counterparts believe people having STIs suffer social stigmas to a reasonable extent ${ }^{48}$. Affected people and their families are often denied basic access to health, and some are even victims of violent attacks ${ }^{50}$. Several authors have advocated for a reduction in STI-related stigma and discrimination, with varying degrees of success $51-59$.

Out of 370 respondents, 308 (83.2\%) said they would be willing to touch persons diagnosed with STIs, so long as the disease in question was not HIV/ AIDS. $28.9 \%$ of the students would not touch persons with HIV/ AIDS. These results are similar to those obtained in Thailand, where $29.47 \%$ of undergraduate students avoided having any direct physical contact with HIV-infected people ${ }^{60}$. In Ghana, as much as $68 \%$ of young adults would not shake hands with people having HIV/ AIDS ${ }^{37}$. If students continue with these attitudes, they will likely treat HIV-infected people badly ${ }^{61}$.

While majority of respondents expressed willingness to touch persons diagnosed with STIs, a far less number entertained the thought of living with the affected persons. As expected, the case was worse with persons diagnosed with HIV/ AIDS. Only $4.3 \%$ said they would be willing to live with persons having HIV/ AIDS. As many as $67.8 \%$ would be willing to live with persons diagnosed with other STIs, certainly not HIV/ AIDS. Only 29.9\% of university students in Thailand expressed willingness to live and work with HIV-infected people 60.

Slightly more than half of the respondents (53.5\%) said they could share kitchen utensils with persons having STIs (other than HIV/ AIDS). Less than half (41.9\%) did not mind sharing kitchen utensils with persons diagnosed with HIV/ AIDS. 15.1\% would rather not share kitchen utensils with HIV-infected persons. A similar result was obtained in Ado Ekiti, southwestern Nigeria where $12 \%$ of secondary school students avoided sharing kitchen utensils with HIV-infected persons for fear of being infected with the virus ${ }^{25}$. 23.6\% of undergraduate students in the University of Abuja, northcentral Nigeria chose not to share kitchen utensils with HIV-infected persons ${ }^{34}$.

$81.9 \%$ said they would be willing to get tested for STIs, while $8.1 \%$ would not want to get tested and $10 \%$ were undecided. $94.1 \%$ would love to have their partners tested for STIs before marriage; $5.1 \%$ did not see the need to subject their partners to the test, and the remaining $0.8 \%$ were undecided.

In terms of accessing treatment if tested positive for one or more STIs, $35.9 \%$ of respondents preferred a Private hospital, $22.7 \%$ opted for an STI clinic (22.7\%), while 21.6\% went for a Government hospital (21.6\%). It is disturbing to note that some respondents (10.8\%) would still choose to visit the Traditional healer for STI treatment, while another $2.2 \%$ would opt for Self-medication. In China, $65.5 \%$ of undergraduate students would see a private doctor for treatment ${ }^{62}$.

All respondents universally agreed that young people need to get information about STIs. In Thailand, a lower number (93\%) of university students agreed that young people should receive more information about STIs ${ }^{42}$.

\subsection{Practices of Respondents Regarding STIs}

Majority (84.1\%) reported having had sex before, while $15.9 \%$ said they had not. More than three quarters (77.8\%) had had sex in the previous three months. 32.7\% had their first sexual encounter before their fifteenth birthday. $30.5 \%$ were not up to 18 years when they had sex for the first time. $16.5 \%$ were below 20 years when they had their first sex. Only $2.7 \%$ said they were above 20 years when they first had sex. $17.6 \%$ did not respond, and this could mean either 
of two things: they were among the few students who had never had sex before, or they were simply unwilling to reveal the age at which they first had sex.

Three quarters (74.9\%) of the respondents had multiple sex partners, while $25.1 \%$ said they did not. The $25.1 \%$ who denied having multiple sex partners probably includes the number of students who never had sex in the first place. A slight majority of the students (28.1\%) had 4 or more sexual partners, $22.2 \%$ had 3, 17.3\% had 2, 16.5\% had only 1 sex partner and $15.9 \%$ had none at all. Majority (45.4\%) said they 'sometimes' use condoms during sexual activity, $18.9 \%$ claimed they 'always' used condoms, while $14.6 \%$ admitted to 'never' using condoms.

Out of the total population, condom use was reported more often among our male students (40\%) than our female students (24.3\%). This was, however, not statistically significant ( $p=1.000)$.

Among those who provided reasons for not using condoms during sex, $16.2 \%$ said it was for 'more sexual satisfaction', while 13.2\% said it was 'for fun (adventure)'. 9.5\% had unprotected sex because they wanted to 'compare with condom use'. $6.8 \%$ claimed they were bowing to 'peer pressure'. Interestingly, $12.4 \%$ said they were sure their body systems and those of their partners were free of STIs, hence there was no need for using condoms. Another $4.6 \%$ said they had unprotected sex because they were afraid of certain 'myths surrounding use of condoms' .

When asked if they use pornographic materials, $78.9 \%$ of the students - including those who claimed they had never had sex - admitted to visiting x-rated internet sites, watching adult movies, reading adult magazines and using other pornographic materials. A lesser number (65.9\%) of undergraduate students in Malaysia had watched/ read pornographic materials ${ }^{47}$.

Almost half (45.9\%) of the respondents reported use of addictive substances (alcohol and/ or other hard drugs) before having sex. A quarter (25.1\%) of the respondents reported ever having sex with commercial sex workers.

Only $44.3 \%$ said they had been tested for HIV although a larger number (66.8\%) had been tested for other STIs. In addition, 55.4\% revealed they had been tested positive for at least one STI. This statistic was high compared to results from other studies. For example, only $3 \%$ of the sexually active population in China had had an STI62. In contrast, in Nigeria, $1.8 \%$ of undergraduate students in the University of Benin had an STI ${ }^{63}$. STI testing was more prevalent among female students (34.6\%) than male students (21\%).

\section{Conclusions}

The students had a relatively high level of awareness about STIs, especially HIV/ AIDS. They had all heard about HIV/ AIDS, but fewer knew about gonorrhoea and syphilis. The least known STIs were trichomoniasis and chlamydia. Indepth knowledge about STIs was still patchy. A number of misconceptions were commonly reported among the students, particularly in areas such as routes of transmission of STIs and STI preventive measures. Most of the students had poor knowledge regarding the complications of untreated STIs. No significant difference was observed in knowledge levels of STIs between male and female students.

Most of the students were worried about contracting STIs and expressed sympathy towards affected persons. But not many of them were willing to share personal items such as clothes, kitchen utensils and food with persons diagnosed with STIs. A far less number were willing to live with or even touch affected persons. The students did not have any problems presenting themselves for STI testing, and they were willing to encourage their partners to do the same.

Even though the students were afraid of contracting STIs, their sexual behavioural patterns were not encouraging. Most of them have been sexually active from a very young age; they have multiple sex partners; and most times they don't bother about using condoms during sexual activity. The use of pornographic materials, alcohol and hard drugs were reported among the students. A section of the students also patronized commercial sex workers. Only few of the students had ever been tested for HIV and other STIs.

No doubt, there is a need to realign STI prevention programs to suit the needs of the young populace. Interventions for health education need to be specifically designed for young adults such that they are better equipped to deal with emerging realities.

\section{Recommendations}

While it can be established that there are routine programs in the university that encourage STI prevention measures among students, the attitudes of the students towards these programs are not very encouraging. The students do not make full use of these intervention measures, thereby exposing themselves to the risk of contracting various STIs, including the dreaded HIV/ AIDS.

Bearing the findings of this research in mind, the following recommendations will be found useful:

- More awareness campaigns are needed to push for sex education programs in colleges and universities. This will go a long way in modifying the risky sexual behaviours of campus students.

- The university should intensify condom use campaigns to discourage their students from having unprotected sex.

- STI education should be incorporated into the curriculum for undergraduate students. This will ensure that students get necessary exposure on a regular basis.

- Schools should organize public discussions and debates on STIs and the influence on the sexuality of their students. Students should be encouraged to participate actively in such eye-opening programs where their confidence levels can be boosted.

- Apart from HIV/AIDS, other STIs like trichomoniasis and syphilis should be given some publicity. Emphasis should be placed on areas where students seem to lack requisite knowledge, such as routes of transmission, preventive measures and complications of untreated STIs. The print media and various social media channels should be employed to generate the needed buzz. 
- Every semester, the university should endeavour to set aside a day or two for free STI testing for students. This will encourage more students to get tested for STIs, especially when they realise that they will not have to pay consultation fees. Schools should make STI testing a routine part of healthcare for students. On-site testing for STIs should be provided, as well as referrals for treatment if the need arises.

- The university's guidance and counseling services should be expanded to include peer counselors who can tailor their interventions to meet the specific needs of students. There is need to strengthen the capacity of this specialized unit so that more personnel can be readily available to help students handle their worries and concerns.

- The university should organize more extra-curricular activities and encourage students to get involved actively, as this would help shift their attention away from intimate encounters to the various sporting activities on offer.

- vix) Governments at all levels should invest more in healthcare. Activities to promote sex education and ensure an STI-free generation will require huge funding. A strong political commitment is absolutely crucial in this regard.

- Students should be enrolled into the National Health Insurance Scheme (NHIS) to ease the burden of out-of-pocket payment for health services.

- Public-private partnerships should be established at all levels to manage and finance healthcare delivery. Governments should encourage and empower private ventures to get involved in the STI eradication agenda.

- More research is needed in this area to encompass a wider audience of undergraduate students such that future spread of STIs is prevented.

\section{References}

i. World Health Organisation, (2005a) Sexually Transmitted Infections among Adolescents: Issues in Adolescent Health and Development, Switzerland: Geneva.

ii. Stine, G. J. (1993) Acquired Immune Deficiency Syndrome. Biological, Medical Social and Legal Issues, Englewood Cliffs, Nj: Prentice hall WHO, (2002). Preventing HIV/ AIDS and Promoting Sexual Health Especially Among Vulnerable Young People. Switzerland: Geneva.

iii. World Health Organisation, (2016) Global Health Observatory (GHO) Data: HIV/AIDS, Available at: http:/ / www.who.int/ gho/ hiv/ en/ (accessed: 19/11/15).

iv. Ombura, J. A., F. O. Ogolla, J. Muola, et al., (2013) 'Knowledge Levels and Use of STI Preventive Measures among University Students in Kenya', Kenya Journal Of Educational Planning, Economics \& Management Volume 6, Issue 1ISSN NO. 2074 -5400, Available at: http:// emskenya.net/ index htm_files/JANE\%20PDF.pdf, (accessed: 12/12/2016).

v. Kalichman, S. C., L. C. Simbayi, and D. Cain, (2010) 'HIV transmission risk behaviours among HIV seropositive sexually transmitted infection clinic patients in Cape Town, South Africa,' European Journal of Public Health, vol. 20, no. 2, pp. 202-206, 2010.

vi. Centers for Disease Prevention and Control, (2013) Incidence, Prevalence, and Cost of Sexually Transmitted Infections in the United States, CDC Fact Sheet, Available at: https:/ / www.cdc.gov/ std/ stats/ sti-estimates-factsheet-feb-2013.pdf, (accessed: 27/ 12/ 2016).

vii. Agboola, I. O., (2010) 'Undergraduate Students Knowledge of HIV/ AIDS and Information Needs: A Study of University of Agriculture, Abeokuta, Nigeria'. Quarterly Publication of Pacific Northwest Library Association (PNLA); 2010.

viii. Temin, M. J., F. E. Okonofua, F. O. Omorodion, et al., (1999), 'Perceptions of Sexual Behavior and Knowledge About Sexually Transmitted Diseases Among Adolescents in Benin City, Nigeria.' International Family Planning Perspectives. 1999;25(4):186-189.

ix. Ombura, J. A., F. O. Ogolla, J. Muola, et al., (2013) 'Knowledge Levels and Use of STI Preventive Measures among University Students in Kenya', Kenya Journal Of Educational Planning, Economics \& Management Volume 6, Issue 1ISSN NO. 2074 -5400, Available at: http:/ / emskenya.net/ index_htm_files/JANE\%20PDF.pdf, (accessed: $12 / 12 / 2016)$.

x. Umukoro, S., (1 February, 2004) 'Nigeria: Lokoja: Untold Story of the North's First Capital', Vanguard, Available at: http:/ / allafrica.com/ stories/ 200402020424.html, (accessed: 12/ 11/ 16)

xi. Ukaegbu, M. O. (2011) Monuments, Historic Preservation and Tourism Development: A Study of Lokoja, Kogi State. A Project Report submitted to the Department of Archaeology and Tourism, Faculty of Arts, University of Nigeria, Nsukka in Partial Fulfillment of the Requirements for the Award Of Master of Arts Degree in Archaeology and Tourism (Tourism Option), Available at: http:/ / www.unn.edu.ng/ publications/ files/ images/ UKAEGBU,\%20MAUREEN\%20OGECHI.pdf, ～（accessed: $05 / 11 / 16)$

xii. Alabi, M. O., (2009a) "Revitalizing Urban Public Open Spaces, Through Vegetative Enclaves in Lokoja, Nigeria", Journal of Geography and Regional Planning vol. 2, no.3.

xiii. Sadibo, W.B and Jacob, A.A (2006) The making of Nigeria: Niger-Benue Confluence Connection. National Commission for Museums and Monuments (NCMM).

xiv. Okpoko, P. U., (1993) The people of Lokoja, in Audah, B. W., A. I. Okpoko, and C. A. Folorunsho (eds.) 'Some Nigerian Peoples'. Special Book Issue, West African Journal of Archaeology. (WAJA).

xv. Alabi, M. O., (2009b) 'Urban Sprawl, Pattern and Measurement in Lokoja, Nigeria', Theoretical and Empirical Researches in Urban Management Number 4(13) / November 2009, Available at: http:/ / um.ase.ro/ No13/ 10.pdf, (accessed: 11/11/16) 
xvi. Audu, M. S. (2009) 'A Reflection on the Nature of Inter-Group-Relations in Lokoja, Nigeria', Journal of Sustainable Development in Africa Vol. 11, no.2; Pennsylvania: Clarion University.

xvii. Creswell, J. W., (2003) Research Design: Qualitative, Quantitative and Mixed Methods Approaches, 2nd ed., Sage, Available at: https:/ / elearning.roehampton-online.com/ bbcswebdav/ pid-19803187-dt-message-rid105749167 6/ internal/ courses/ UKR1.80171.201680/ db/ 19803187_1/ embedded/ 2003 creswell aframework-for-design.pdf, (accessed: 09/ 09/16)

xviii. Savin-Baden, M. \& C. Major, (2013) Qualitative Research: The Essential Guide to Theory and Practice. London: Routledge.

xix. Yamaguchi, Y., P. Sriareporn, P. Khiaokham, et al. (2016) 'Knowledge, Attitude, and Practice Concerning the Prevention of STIs among High School Students in Northern, Thailand', Universal Journal of Public Health 4(1): 815, 2016, Available at: http:/ / www.hrpub.org DOI: 10.13189/ ujph.2016.040102, (accessed: 03/ 10/ 16)

xx. Temin, M. J., F. E. Okonofua, F. O. Omorodion, et al., (1999), 'Perceptions of Sexual Behavior and Knowledge About Sexually Transmitted Diseases Among Adolescents in Benin City, Nigeria.' International Family Planning Perspectives. 1999;25(4):186-189.

xxi. Gitonga, M., M. Sinyard, and G. Gachuiri, (2012) 'Alcohol and Substance Use viz a viz HIV Sexual Risk Behaviours among Freshmen Students at a Kenyan University College: Focus for Interventions'. Journal of Biology, Agriculture and Healthcare. 2012;2(8):8-12.

xxii. Sutton, M. Y., F. P. Hardnett, P. Wright, et al., (2011) 'HIV/ AIDS knowledge scores and perceptions of risk among African American students attending Historically Black Colleges and Universities'. Public Health Rep. 2011;126:653-663. Available at: http:/ / www.ncbi.nlm.nih.gov/ pubmed/ 21886325, (accessed: 01/ 01/ 2017).

xxiii. Mafany, N. M., J. K. Mati, and B. T. Nasah, (1990) 'Knowledge of and attitudes towards sexually transmitted diseases among secondary school students in Fako District Cameroun.' East African Medical Journal. 1990 Oct; 67(10);706-711, Available at: http:// ncbi.nlm.nih.gov/ pubmed/ 2282892

xxiv. Aliyu, A. A., T. Dahiru, A. M. Ladan. et al., (2013) 'Knowledge, sources of information, and risk factors for sexually trasnmitted infections among secondary school youths in Zaria, Northern Nigeria'. Journal of Medicine in the Tropics, Vol. 15, No. 2, 2013

xxv. Amu, E. O. and P. T. Adegun, (2015) 'Awareness and Knowledge of Sexually Transmitted Infections among Secondary School Adolescents in Ado Ekiti, South Western Nigeria'. Journal of Sexually Transmitted Diseases Volume 2015, Article ID 260126. Available at: http:/ / hindawi.com/ journals/ jstd/ 2015/ 260126

xxvi. Sekirime, W. K., J. Tamale, J. C. Lule, and F. Wabwire-Mangen, (2001) 'Knowledge, Attitude and Practice about Sexually Transmitted Diseases among University students in Kampala'. African Health Sciences. 2001;1(1):16-20. Available at: http:/ / ncbi.nlm.nih.gov/ pmc/ articles/ PMC2704443.

xxvii. Awang, H., L. P. Wong, R. Jani, and W. Y. Low, (2014) 'Knowledge of sexually ransmitted diseases and sexual behaviours among malaysian male youths'. Journal of Biosocial Science, Vol. 46, No. 2, pp. 214-224, 2014. Available at: http:/ / www.ncbi.nlm.nih.gov/ pubmed/ 23480474, (accessed: 01/ 12/ 16)

xxviii. Albrektsson, M., L. Alm, X. Tan, and R. Andersson, (2009) 'HIV/ AIDS awareness, attitudes and risk behavior among university students in Wuhan, China.' Open AIDS Journal. 2009;3:55-62.

xxix. Paz-Bailey, G., P. H. Klimarx, S. Supawitklul, S., et al., (2003) 'Risk factors for sexually transmitted diseases in northern Thai adolescents: an audio-computer-assisted self-interview with noninvasive specimen collection'. Sexually Transmitted Diseases, 30(4):320-6

xxx. World Health Organisation, (2005b) Sexually transmitted and other reproductive tract infections: a guide to essential practice. Geneva: WHO; 2005.

xxxi. World Health Organisation, (2007) Global strategy for the prevention and control of sexually transmitted infections: 2006-2015. Breaking the chain of transmission. Geneva: WHO; 2007.

xxxii. Goundry, A. L. R., E. R. Finlay and C. D. Llewellyn, (2013) 'Talking about links between sexually transmitted infections and infertility with college and university students from SE England, UK: a qualitative study', Reproductive Health201310:47, Available at: journal.biomedcentral.com/ articles/ 10.1186/ 1742-4755-10-47, (accessed: 22/ 12/ 2016)

xxxiii. Iyaniwura, C. A. and O. Okusanya, (2005) 'Sexual Practices related to STIs and HIV among Refugees at Oru camp, Ogun State'. Nigerian Medical Practitioner. 2005;47(5):87-93.

xxxiv. Makwe, E. and M. O. Adenyuma, (2014) 'Awareness of Sexually Transmitted Infections (STIs) Including HIV/ AIDS among Undergraduate Students of University of Abuja, Nigeria', British Journal of Applied Science \& Technology 4(4): 705-717, 2014.

xxxv. Shiferaw, Y., A. Alemu, A. Girma, et al., (2011) 'Assessment of Knowledge, Attitude and Risk Behaviors Towards HIV/ AIDS and other Sexual Transmitted Infection among Preparatory Students of Gondar Town, North West Ethiopia'. Biomed Central Journal. 2011;4:505.

xxxvi. Amu, E. O. and P. T. Adegun, (2015) 'Awareness and Knowledge of Sexually Transmitted Infections among Secondary School Adolescents in Ado Ekiti, South Western Nigeria'. Journal of Sexually Transmitted Diseases Volume 2015, Article ID 260126. Available at: http:/ / hindawi.com/ journals/ jstd/ 2015/ 260126

xxxvii. Anarfi,J. K. and P. Antwi, (1995) 'Street youth in Accra city: Sexual networking in a high- risk

xxxviii. Kumar, V., A. K. Abbas, N. Fausto \& R. N. Mitchell (2007), Robbins Basic Pathology (8th ed.), Saunders Elsevier.

xxxix. McManus, A. and L. Dhar, (2008) 'Study of knowledge, perception and attitude of adolescent girls towards STIs/ HIV, safer sex and sex education: A cross sectional survey of urban adolescent school girls in South Delhi, India'. BMCWomen's Health. 2008;8:12. 
xl. Mafany, N. M., J. K. Mati, and B. T. Nasah, (1990) 'Knowledge of and attitudes towards sexually transmitted diseases among secondary school students in Fako District Cameroun.' East African Medical Journal. 1990 Oct; 67(10);706-711, Available at: http:// ncbi.nlm.nih.gov/ pubmed/ 2282892.

xli. Asante, K. O., (2013) 'HIV/ AIDS Awareness and Uptake of HIV Counseling and Testing among Undergraduate Private University Students in Accra, Ghana'. Reproductive Health 10:17.

xlii. Svensson, L. and S. Waern, (2013) Knowledge of and attitudes to sexually transmitted diseases among Thai university students. Department of Public Health and Caring Sciences, Uppsala University, Sweden.

xliii. Lan, P. T., C. S. Lundborg, I. Mogren, et al., (2009) 'Lack of knowledge about sexually transmitted infections among women in North rural Vietnam'. BMC Infectious Diseases 2009, 9:85, Available at: http:/ / bmcinfectdis.biomedcentral.com/articles/ 10.1186/ 1471-2334-9-85, (accessed: 20/ 12/ 2016).

xliv. Rondini, S. and J. K. Krugu, (2009) 'Knowledge, attitude and practices study on reproductive health among secondary school students in Bolgatanga, upper east region'. African Journal of Reproductive Health. 13(4):51-66.

xlv. Abel, G. and C. Brunton, (2005) 'Young people's use of condoms and their perceived vulnerability to sexually transmitted infections,' Aust N Z J Public Health 2005 Jun;29(3):254-260. Available at: http:// ncbi.nlm.nih.gov/ pubmed/ 15991774.

xlvi. Thato S., Charron-Prochownik D., Dorn L. D., Albrecht S. A. \& Stone C. A. (2003) Predictors of Condom Use Among Adolescent Thai Vocational Students. Journal of Nursing Scholarship, 35(2):157-63.

xlvii. Folasayo, A. T., A. J. Oluwasegun, S. Samsudin, et al., (2017) 'Assessing the Knowledge Level, Attitudes, Risky Behaviours and Preventive Practices on Sexually Transmitted Diseases among University Students as Future Healthcare Providers in the Central Zone of Malaysia: A Cross-Sectional Study', International Journal of Environmental Research and Public Health 2017, 14, 159.

xlviii. Cockrill, M. (2004) 'Sexually Transmitted Infections, Social Stigmas and Gender Differences', Psychology \& Women Studies, University of Washington, 2003-2004.

xlix. Balfe, M., R. Brugha, D. O. Donovan, et al., (2010) 'Triggers of self-conscious emotions in the sexually transmitted infection testing process', BMC Res Notes. 2010; 3:229. Available at: http:/ / ncbi.nlm.nih.gov/ pmc/articles/ PMC2930645, (accessed: 31/ 12/ 16)

1. Stangi, A. L. and C. I. Grossman, (2013) 'Global Action to reduce HIV stigma and discrimination', J Int AIDS Soc. 2013; 1693Suppl 2):18934. Available at: http:/ / ncbi.nlm.nih.gov/ pmc/ articles/ PMC3834870

li. Brown, L., K. Macintyre, and L. Trujillo, (2003) 'Interventions to reduce HIV/ AIDS stigma: what have we learned?' AIDS Educ Prev. 2003;15(1):49-69.

lii. Nyblade, L., (2006) 'Measuring HIV stigma: existing knowledge and gaps.' Psychol Health Med. 2006;11(3):335-45

liii. Kidd, R., S. Clay, and C. Chiiya, 'Uunderstanding and challenging HIV stigma: toolkit for action. Brighton, UK: International HIV/ AIDS Alliance, CHANGE Project, Academy for Education Development (AED), International Center for Research on Women (ICRW), PACT Tanzania; 2007.

liv. Nyblade, L., K. T. Hong, N. V. Anh, et al., (2008) Communities confront HIV stigma in Viet Nam: participatory interventions reduce HIV-related stigma in two provinces. Washington, DC: International Center for Research on Women (ICRW); 2008. pp. 1-37

lv. Earnshaw, V. A. and S. R. Chaudoir, (2009) 'From conceptualising to measuring HIV stigma: a review of HIV stigma mechanism measures'. AIDS Behav. 2009;13(6):1160-77.

lvi. Pulerwitz, J., A. Michaelis, E. Weiss, et al., (2010) 'Reducing HIV/ AIDS-related stigma: lessons learned from horizons research and programs.' Public Health Rrep. 2010;125(2):272-81

lvii. Sengupta, S., B. Banks, D. Jonas, et al., (2011) 'HIV interventions to reduce HIV/ AIDS stigma: a systematic review'. AIDS Behav. 2011;15(6):1075-87.

lviii. Rao, D., M. Desmond, M. Andrasik, et al., (2012) 'Feasibility, acceptability, and preliminary efficacy of the unity workshop: an internalized stigma reduction intervention for African American women living with HIV.' AIDS Patient Care STDS. 2012;26(10):614-20.

lix. Li, L., Z. Wu, L. J. Liang, et al., (2013) Reducing HIV-related stigma in health care settings: a randomized controlled trial in China'. Am J Public Health. 2013; 103(2);286-92.

lx. Wilailak, O., (2014) 'Prevention Behaviour to Sexually Transmitted Diseases and AIDS of University Students', Procedia - Social and Behavioural Sciences. 7 February 2014, Vol 112: 525-531. Available at: http:/ / sciencedirect.com/ science/ article/ pii/ S1877042814012154, (accessed: 31/ 12/ 16).

lxi. Prapan, P., (2009) 'The Statistics of HIV Test being Conducted on People Coming to Receive Services'. The Thai Red Cross Anonymous Clinic. Bangkok, 1.

lxii. Zhang, D., H. Pan, B. Cui. et al., (2013) 'Sexual behaviours and awareness of sexually transmitted infections among Chinese university students'.J Infect Dev Ctries. 2013; 7(12): 966-974

lxiii. Omobude-Idiado, S. N. and G. N. Bazuaye, (2009) 'Patterns of Sexually Transmitted Infections (STIs) reported among students in a federal university in Midwestern Nigeria'. College Student Journal. June, 2009 Vol 43, Issue 2. Available at: http:// freepatentsonline.com/article/ College-Student-Journal/201608600.html, （accessed: 02/01/17) 